
10 Nordic Council
of Ministers

\title{
Economic values from the natural and cultural heritage in the Nordic countries
}

Improving visibility and integrating natural and cultural resource values in Nordic countries 



\section{Economic values from the natural and cultural heritage in the Nordic countries}

Improving visibility and integrating natural and cultural resource values in Nordic countries

Fredrik Gisselman, Scott Cole, Josefin Blanck, Matleena Kniivilä, Nora Skjeerna Hansen and Elin Fornbacke

TemaNord 2017:522 
Economic values from the natural and cultural heritage in the Nordic countries

Improving visibility and integrating natural and cultural resource values in Nordic countries

Fredrik Gisselman, Scott Cole, Josefin Blanck, Matleena Kniivilä, Nora Skjeerna Hansen and Elin Fornbacke

ISBN 978-92-893-4952-9 (PRINT)

ISBN 978-92-893-4953-6 (PDF)

ISBN 978-92-893-4954-3 (EPUB)

http://dx.doi.org/10.6027/TN2017-522

TemaNord 2017:522

ISSN 0908-6692

Standard: PDF/UA-1

ISO 14289-1

(c) Nordic Council of Ministers 2017

Layout:NMR

Cover photo: unsplash.com/Drew Coffman

Print: Rosendahls

Printed in Denmark

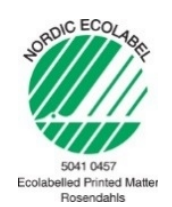

Although the Nordic Council of Ministers funded this publication, the contents do not necessarily reflect its views, policies or recommendations.

\section{Nordic co-operation}

Nordic co-operation is one of the world's most extensive forms of regional collaboration, involving Denmark, Finland, Iceland, Norway, Sweden, the Faroe Islands, Greenland, and Åland.

Nordic co-operation has firm traditions in politics, the economy, and culture. It plays an important role in European and international collaboration, and aims at creating a strong Nordic community in a strong Europe.

Nordic co-operation seeks to safeguard Nordic and regional interests and principles in the global community. Shared Nordic values help the region solidify its position as one of the world's most innovative and competitive. 


\section{Contents}

Popular Summary

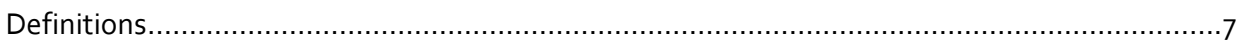

Foreword

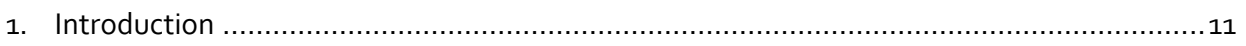

2. Initiatives and programs for protecting natural and cultural heritage in the

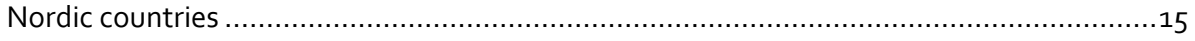

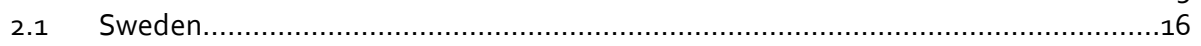

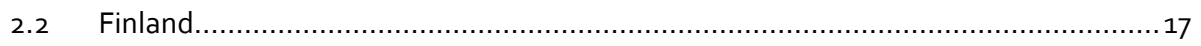

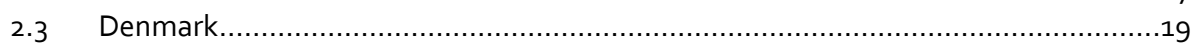

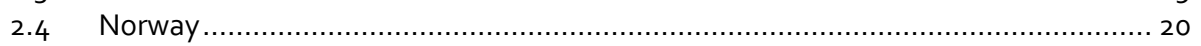

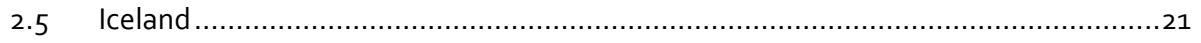

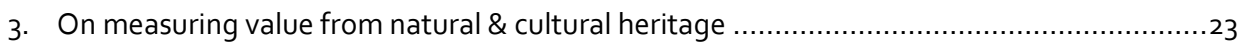

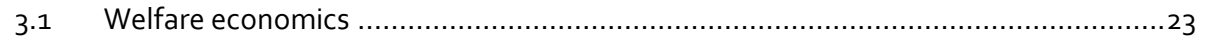

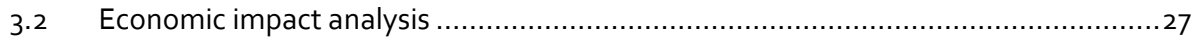

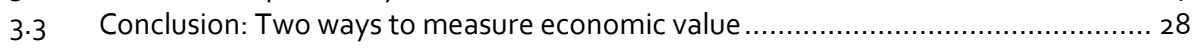

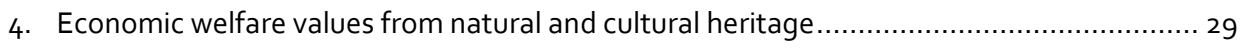

4.1 Literature summary: Economic values from landscape scenery, cultural heritage

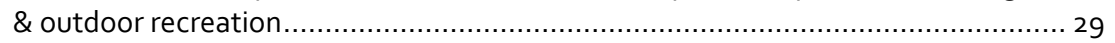

4.2 Literature summary: Economic values from biodiversity ............................. 31

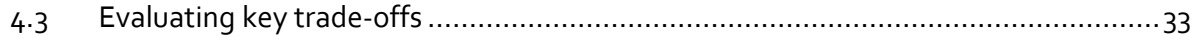

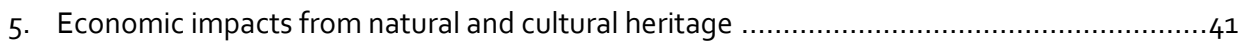

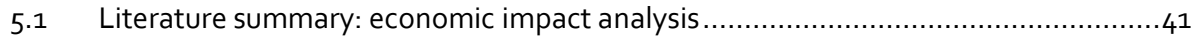

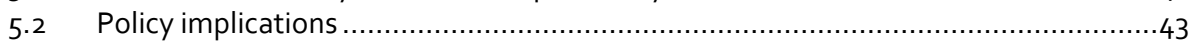

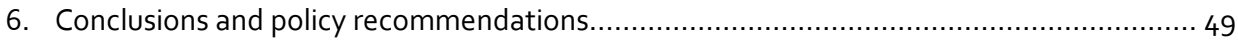

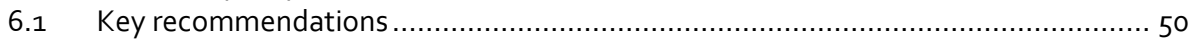

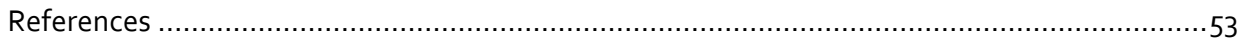

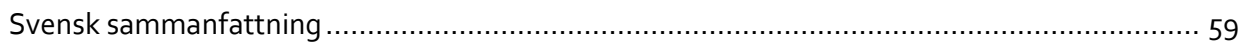

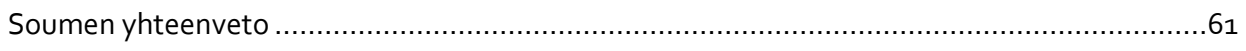

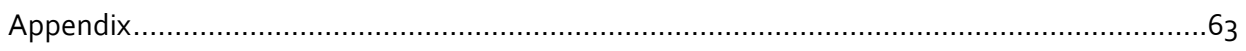

Appendix 1: Studies that illustrate economic values from landscape scenery, cultural

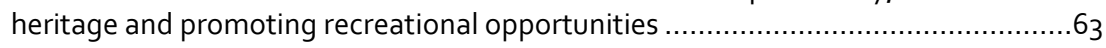

Appendix 2: Studies that illustrate the economic values associated with biodiversity .......66 66 



\section{Popular Summary}

Natural and cultural heritage represent key assets that deliver different kind of benefits to citizens in the Nordic countries. This report illustrates the economic values at stake and discusses the important and inevitable key trade-offs facing decision-makers charged with managing these assets.

The report has three goals: to briefly describe existing conservation measures in the Nordic countries, to illustrate the type and magnitude of economic values generated by these measures, and to discuss key trade-offs and policy implications arising from the selection of measures, which lead to welfare impacts depending on the level of human use. The goal is to identify how economics can provide insight to inform better decision-making and support concrete policy recommendations. The study focused on the Nordic countries, primarily Denmark, Finland and Sweden, but also covered Iceland and Norway. The analysis relied on existing economic literature.

The starting point for our evaluation is the assessment of welfare benefits (wellbeing) generated by natural and cultural heritage via the total economic value framework (TEV). By using this framework it is possible to identify the universe of potential economic benefits to society that may arise from the areas. The benefits include direct use values such as recreational experiences and indirect use values such as increased resilience. Additional benefits can be classified as non-use values (e.g., those generated from individuals who may never visit the area).

The valuation studies reviewed demonstrate real economic values associated with the experiences that natural and cultural heritage provides. Ordinary citizens, recreationists and/or tourists experience improved well-being (welfare) from the protection of natural and cultural heritage and have demonstrated a willingness to pay for measures that increase the quantity or quality of these experiences.

Furthermore, regional economic studies demonstrate additional "market-based" economic benefits related to employment and income. The key variable driving positive regional economic impacts is the number of visitors to a site, but other factors such as the level of restrictions, the location of the site, services offered, environmental attributes, cost of access, designation status, existence of complementary sites and/or attractions in the vicinity can affect whether a site actually produces economic benefits. The structures of the local economy and leakages to neighboring areas (e.g. taxes are not payed locally) also have an impact on the magnitude of local impacts.

That different types of conservation measures lead to market and non-market benefits does not, in itself, motivate a certain level of conservation or protection. Instead, this report demonstrates how welfare can only be improved by comparing the opportunity costs of a measure to its benefits. Doing so requires the assessment of key trade-offs. The most common types of trade-offs are those between values associated with conservation on the one hand and development on the other (e.g. forestry or 
construction), between different types of recreational user groups (e.g. noisy vs. quiet) or between competing biodiversity goals. The suggested framework for addressing the trade-offs associated with alternative land use decisions is cost-benefit analysis.

The main recommendations of this study are: (1) Measure and capture welfare benefits. Measures aimed at protecting natural and cultural heritage sites should be based on maximizing the net economic welfare and this requires that economic benefits are measured, preferably in monetary terms, (2) Measure and capture regional economic impacts. A complement to welfare benefits are the economic impacts measured in markets that tend to arise locally from the protection of cultural and natural heritage. Additional effort should be focused on using available economic methods to measure how specific measures can affect income, taxes and job creation. 


\section{Definitions}

- Natural heritage: In this study, we interpret natural heritage as the sum of the elements of biodiversity together with geological structures and formations.

- Cultural heritage: We focus on the tangible aspects of cultural heritage, primarily those closely related to natural heritage such as culturally significant landscapes.

- Willingness to pay (WTP): WTP is the maximum amount an individual would pay for a marginal increase in a specific good or service.

- Willingness to accept (WTA): WTA is the minimum compensation an individual would accept for loosing a good or service they already own or are entitled to.

- Direct economic impacts: Economic effects from changes in income, sales and jobs in the businesses that directly receive payments, e.g. visitor spending.

- Indirect impacts: Effects from changed income, sales or jobs in the industries that supply services or goods to businesses that sell directly to the consumers. For example, accounting companies might benefit when new companies associated with tourism are established as a result from increased visitor spending.

- Induced impacts: Effects from changes resulting from increased household spending as a result of increased income earned through a direct or indirect effect of e.g. visitor spending. For example, guides or hotel employees living in the region spend income on housing, groceries, and other goods and services. 



\section{Foreword}

This report is designed to help the Nordic Council of Ministers, specifically the Terrestrial Ecosystem Group (TEG) and decision-makers at national, regional and local levels in the Nordic countries, to better understand the nature and magnitude of economic values generated by natural and cultural heritage and the different kinds of trade-offs related to policies that favor conservation or extraction. The information can be used to better evaluate economic consequences of management decisions - both welfare benefits and economic impacts on the local level - and improve policy design to help achieve both conservation and development goals. The report provides insight into the conservation policies of natural and cultural heritage of various Nordic countries to facilitate better partnerships, while also lifting international examples and best practices. 



\section{Introduction}

The natural and cultural heritage in the Nordic countries includes environmental and natural resources such as forests, wilderness, scenic landscapes, rivers, lakes and marine areas, as well as cultural resources such as historic buildings, structures or other human influences on the natural environment that we pass on to future generations. Some of these resources have protected designation status, which restricts development and certain activities - but others do not. This raises several important questions: what are the types (and magnitudes) of values generated from conserving these areas and how might the realization of these values by society differ, depending on how these areas are managed? Ultimately, this information can be used to improve future resource management decisions.

There are, of course, several types of economic benefits, some of which are easier to measure than others. One category of benefit focuses on economic impacts generated by the market economy such as the generation of labour income for individuals, companies and/or governments, the number of jobs created or the economic output or valued added to the economy. These impacts, covered in Section 3.2, are important locally as they may result in a net inflow or outflow of financial resources to a particular community affected by conservation.

Another type of benefit, which is much wider, is referred to as economic welfare benefits. These benefits, discussed in Section 3.1, are frequently captured outside of the typical market indicators, but are nonetheless important as they affect individuals' (and by extension society's) well-being. This report puts particular emphasis on these types of social benefits, which should be compared to the social costs in a Cost Benefit Analysis (CBA).

As the terms natural and cultural heritage is not commonly used in the economic valuation literature, we focus on three different attributes that characterize natural and cultural heritage, which also is the main driver for protection of natural and cultural heritage sites:

- Protection of biodiversity.

- Preservation of natural landscapes and cultural heritage.

- Promoting and enabling outdoor recreation. 
These benefits are often linked to the provision of ecosystem services (Millennium Ecosystem Assessment 2005, TEEB 2010), ${ }^{1}$ which contribute directly and indirectly to individuals' well-being or welfare through:

- Cultural experiences related to human history and the development of ideas and ways of life.

- Recreational experiences provide direct use values, e.g., hiking, skiing, camping, cycling and berry and mushroom picking.

- Knowing that certain plant and animal species exist can contribute to our well-being even if we never have the opportunity to see or experience them (non-use values).

- Plant and animal species that are not "used" directly today may nonetheless provide value based on the opportunity for using them in the future (so-called option value).

- Ecosystem diversity ensures better ecosystem function, which in turn leads to an increase in the quantity and quality of ecosystem services. Diverse ecosystems are also more resilient than homogenous ecosystems. Since people tend to value stability and are, in general, risk averse, diverse ecosystems thus provide insurance values, i.e. the value people put on security and predictability.

In a world of scarce resources for managing natural and cultural heritage, decisionmakers need clear information about the costs and benefits of alternative policies, investments or projects. Otherwise society's limited resources will be wasted and public policies will be suboptimal. For example, information on the type and magnitude of values generated can help address questions such as: Do we want to develop and consume our natural and cultural heritage resources today, protect them so that future generations can use them, or establish long-lasting protection for both current and future generations?

Sometimes synergies exist between values: e.g., recreational uses like hiking and cycling can be protected in a way that also promotes berry and mushroom picking. Forestry and recreational use can often be practiced in the same areas. But in other cases, conflicts can arise. For example, an infrastructure project may impose a cost on recreational users, historic sites and/or a valuable wetland. ${ }^{2}$ In these cases, welfare economics can help by measuring the costs and welfare benefits of alternative policies and suggesting how policy may be better designed to ensure the protection of key values. However, one of the biggest challenges facing decision-makers today are defining and measuring the value generated from a specific protection of a natural or cultural resource and determining who wins and who loses from a given policy.

\footnotetext{
${ }^{1}$ This report focuses on a subset of ecosystem services that are related to natural and cultural heritage. It naturally excludes other inputs that contribute to human well-being such as water purification or crop pollination.

2 Table 12.1 in TEEB 2012 for a summary of synergies and conflicts that arise in Nordic countries when managing biodivesity and ecosystem services.
} 
The reason this is so challenging is because prices are often used as signals for the value people place on goods and services, but the benefits provided by these resources are generally invisible to the market system. Thus, it is hard for decisions-makers to see the value gained or lost from changes in natural and cultural history. This is a problem that economists refer to as a market failure, ${ }^{3}$ which increases the risk that decision-makers make poor decisions as they rely on partial or incomplete information. For example, society's well-being may decrease when valuable but un-priced conservation lands are irreversibly developed to provide short-term economic benefits that are more easily measured in monetary terms (e.g., the contribution of new infrastructure to economic output). One way of addressing the risk of "undervaluing" these benefits is to rely on economic methods that highlight these values.

This report aims to make visible the economic values generated by natural and cultural heritage in the Nordic countries, - in particular non-market values - which can provide information about the values at stake when assessing projects, investments or policies that affect natural and cultural heritage. While the results of this report cannot prevent local disagreements or resolve all disputes about the value of habitat $\mathrm{X}$ vs. habitat $Y$ or land-use alternative 1 vs. alternative 2 , it can nonetheless provide inputs to a more transparent and defensible decision-making process. This not only provides more clarity for private actors but also generates insight into how non-market values can be integrated to improve future decision-making on the public level. By identifying values explicitly - rather than relying on hidden values that are often "implied" by existing or past decisions - this report makes a key contribution: it highlights the inevitable trade-offs associated with conservation measures which, in turn, can alter the management of natural and cultural heritage so that key values from these resources are realized.

The main objectives of this report are to:

- Briefly describe existing initiatives for protecting natural and cultural heritage in the Nordic countries with a specific focus on regulations and restriction (Chapter 2).

- Describe the contribution of economics in assessing the value of these resources (Chapter 3).

- Highlight the type and magnitude of values from the literature, including both welfare value and economic impacts (Chapter 3, 4 and 5, respectively).

- Discuss key trade-offs and policy implications related to the economic value of these resources and provide insight on how economics can inform better decisionmaking (Chapters 4.3 and 5.2).

- Summarize key conclusions and policy recommendations (Chapter 6).

3 Here the free market system fails because the price of a good or service does not coincide with the actual value it provides society. 
The study focuses on the Nordic countries, primarily Denmark, Finland and Sweden, but also covers Iceland and Norway. The report relies on literature reviews, interviews with experts, and own analyses of decisions related to the protection of natural and cultural heritage. The study takes an anthropocentric approach: i.e. the focus of economic valuation is to identify and quantify the increase in utility (well-being) individuals obtain from the existence of market and non-market values associated with natural and cultural heritage.

Figure 1: Boats longing for summer, Gotland Sweden

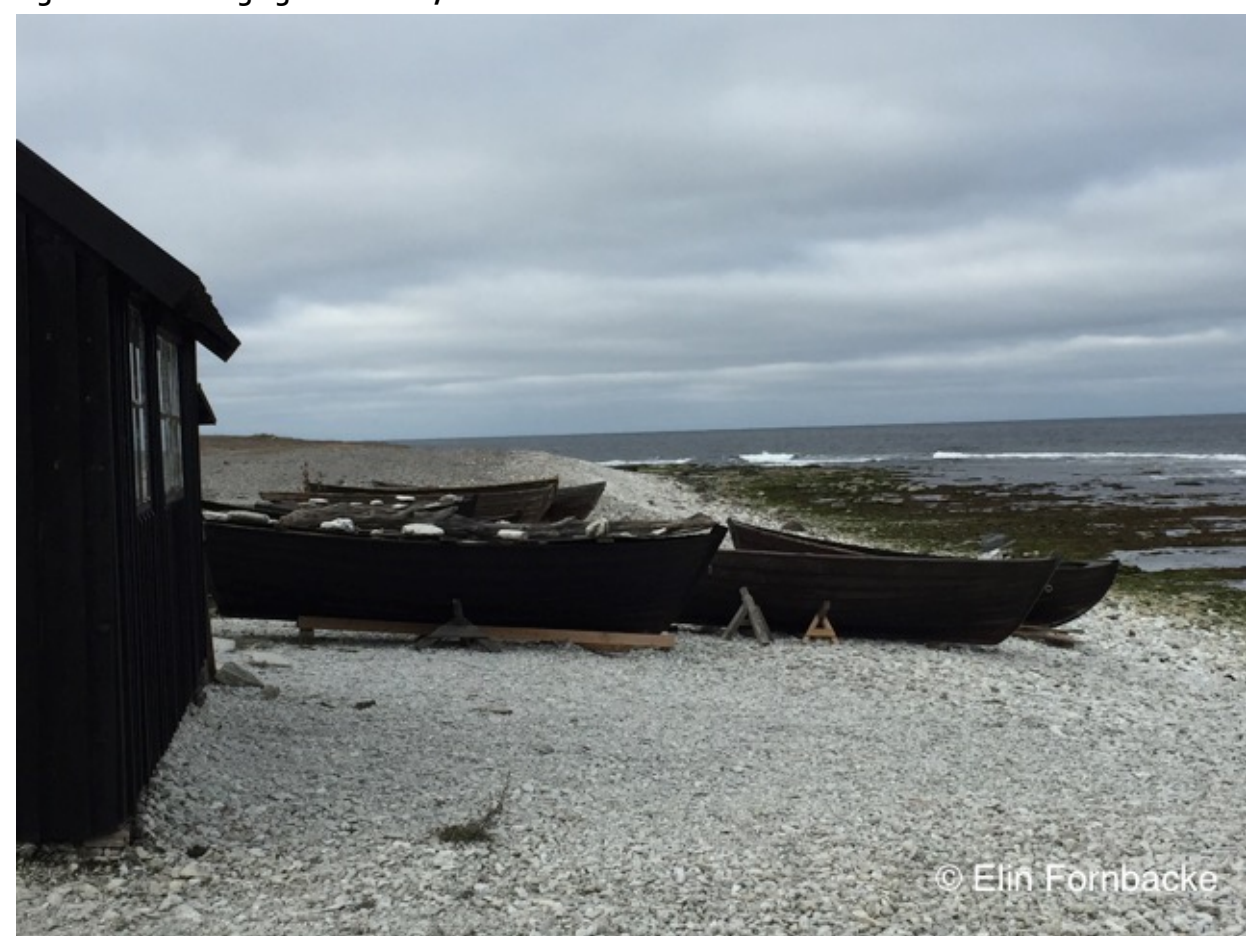




\section{Initiatives and programs for protecting natural and cultural heritage in the Nordic countries}

As natural and cultural heritage sites provide values to society, the Nordic countries have various programs and initiatives aiming to protect these areas to ensure that they will continue to generate value. While the goal and the challenges are mostly similar in all Nordic countries the conservation strategies differ between the countries.

A common feature in the Nordic countries is the right of public access, which ensures every ones access to nature regardless of who owns the land. Rules vary slightly especially for Denmark where the full right of access only exists on public land but is limited to roads and paths during daytime in the private forests. The right of access can also be limited in some protected areas but in general the right of access is quite unique and it ensures common benefits from natural and cultural heritage in the Nordic countries.

Protected areas are regulated by the different domestic Nordic legislations and there is some variation when it comes to regulations and restrictions. Many of the programmes and initiatives have evident similarities but there are significant differences, both in the national legislation and in the local regulations at specific conservation sites.

Given that the attributes of a protected designation (such as e.g. restrictions on human use, treatment of certain species type) are the most important drivers of economic value, and because these attributes can vary significantly across countries, it is not possible for this report to assess the economic values per designation type, (e.g., Natura 2000, nature reserve, national park, etc.). Therefore, this study focuses more broadly on how different types of protection measures can lead to the expression or restriction of economic values and, most importantly, how management of these resources can influence which economic values are generated. However, National parks may be established in areas considered outstanding in landscape, flora or fauna, or having special historic significance. Protection of areas with high natural and/or cultural values can be done in different ways depending on the chosen strategy and focus of the protection. Different restrictions and regulations are applied at different sites, which might result in various trade-offs regarding what types of value that is generated.

The following section gives a brief background on initiatives aiming to protect natural and cultural heritage in each of the Nordic countries. As the different restrictions and regulations from these initiatives affects the type and magnitude of value generated, a specific emphasis lie on providing an overview of the existing differences regarding the relevant restrictions and regulations. 


\subsection{Sweden}

There are various forms of conservation measures that protect both cultural and natural heritage in Sweden. More than $13 \%$ of the country's land surface is protected through nature conservation programs with legal protection. ${ }^{4}$ Nature reserves are the dominant form of protection based on land surfaces covered. In Sweden, nature reserves are covering approximately $84 \%$ of the total protected area. ${ }^{5}$ There are also 29 national parks spread across the country. ${ }^{6}$ Most of these two designations are also protected as Natura 2000 areas through the EU Birds and Habitats Directives. There are about 4,000 Natura 2000 areas in Sweden. ${ }^{7}$ In addition, there are 43 cultural reserves in which the area's natural and cultural values are protected. These include buildings, structures, remnants and land.

A number of voluntary programs have been initiated to protect the country's natural and cultural heritage. The most extensive is the voluntary set-aside forest programs. Forest companies have set aside around 1.35 million ha of forestland through the voluntary programs according to The Swedish Forest Industries Federation. ${ }^{8}$ If the landowner is certified according to the FSC standard at least 0.5 hectares of contiguous productive forest must be set aside for nature conservation. The land must have high natural- and/or cultural values or provide value for recreation and outdoor activities. ${ }^{9}$ One example of a voluntary conservation program is the Eco park initiative initiated by the state owned forest company Sveaskog. Sveaskog has set aside 175,000 hectare of forest land ( $5 \%$ of their forest holdings) with high social and/or ecological values. Sveaskog has signed legally binding agreements with the Swedish Forest Agency for about 100,000 hectares. ${ }^{10}$

Another conservation program is the UNESCO World Heritage Sites. There are 15 UNESCO World Heritage sites in Sweden, with the vast majority (14 of 15 sites) protected based on their cultural value. These sites are not legally protected but recognized internationally as a valuable legacy to be passed on to future generations. There are many types of cultural and historical values that are being protected through the World Heritage Convention. One Swedish example is Björkö Island and Hovgården, consisting of two sites with historical and cultural heritage from the gth and 1oth centuries. These archaeological sites located close to Stockholm are heritage from the advanced trading networks of the Viking-Age in Europe. Another example of a Swedish World Heritage Site is the protection of the cultural agricultural landscape on the island

\footnotetext{
4 The $13 \%$ includes following forms of protection: (1) Natura 2000, (2) Nature reserves, (3) National parks, (4) Wetlands protected under the Wetlands Convention, (5) Specific habitat protection, (6) Areas protected for a defined time under conservation agreements supported by the Land Code. Source: http://www.naturvardsverket.se/Miljoarbete-isamhallet/Miljoarbete-i-Sverige/Uppdelat-efter-omrade/Naturvard/Skydd-av-natur/

5 http://www.scb.se/sv_/Hitta-statistik/Statistik-efter-amne/Miljo/Markanvandning/Skyddad-natur/24541/24548/Behallarefor-Press/390529/

${ }^{6}$ https://www.sverigesnationalparker.se/om-sveriges-nationalparker/skyddad-natur-i-sverige/

7 Se ovan

${ }^{8}$ http://skyddadskog.se

9 http://www.skogsstyrelsen.se/Myndigheten/Skog-och-miljo/Skyddad-skog/Frivilliga-avsattningar/

${ }^{10}$ http://www.sveaskog.se/Documents/Trycksaker/Ekoparksmaterial/Våra\%2oekoparker\%2osve.pdf
} 
Öland. The environment is protected as it has traces from human settlement from prehistoric times to the present day.

\section{Regulations and restrictions}

International commitments, national environmental legislation and the Environmental Code provide the basis for environmental work in Sweden. The Swedish Environmental Code sets the general frame for protection but the single sites often have specific regulations. Thus, there is a variation regarding what is allowed and what is prohibited. For example, in some nature reserves motor vehicles are allowed while it in others can be prohibited to walk outside marked trails. ${ }^{11}$ Information signs regarding what is allowed are required to inform the public about the rules and regulations for every reserve. The strongest protection form in Sweden is the national parks. ${ }^{12}$ Sweden was the first country in Europe to establish national parks in 1909 and it is the government and the parliament that decides when are where to establish national parks. ${ }^{13}$

\subsection{Finland}

Finland has various conservation measures to protect both cultural and natural heritage. Biodiversity is most commonly protected through establishment of conservation areas, which in Finland include e.g. national parks, strict nature reserves and other state-owned protected nature reserves. ${ }^{14}$ In addition, there are also nature reserves in privately owned areas.

The main legislation for protecting natural and cultural heritage in Finland is the Nature Conservation Act. In addition e.g. the Forest Act, the Outdoor Recreation Act, the Land Use and Building Act and the Act on the Protection of Rapids also provide rules related to conservation. Under the Finnish Wilderness Act, wilderness areas have been established in northern mountain and forest areas in Lapland. In total, about $9 \%$ of Finland's land area is protected under the Nature Conservation Act and the Wilderness Act. ${ }^{15}$ Most of these areas are also part of the EU Natura 2000 program.

Finland is Europe's most densely forested country, covering over 3/4 of the total land area. ${ }^{16}$ About $12 \%$ of forest is protected and a significant part of the conserved areas are located in northern part of the country. ${ }^{17}$ Protected forestland includes both productive forests and poorly productive forestland. Protected forests consist of forests in statutory protected areas and of biodiversity conservation sites in commercial forests. Most of these forests are conserved under the Nature Conservation Act and are

\footnotetext{
${ }^{11}$ http://www.naturvardsverket.se/Var-natur/Skyddad-natur/Naturreservat/

12 http://www.naturvardsverket.se/Var-natur/Skyddad-natur/Nationalparker/

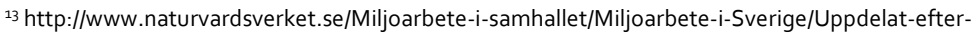

omrade/Naturvard/Skydd-av-natur/Nationalparksplan-for-Sverige/

${ }^{14}$ www.ymparisto.fi

15 www.ymparisto.fi

${ }^{16}$ http://www.metla.fi/metla/finland/finland-forests.htm

17 Luonnonvarakeskus 2016
} 
state-owned and managed by Metsähallitus. ${ }^{18}$ There are also other commercial forestland where economic activates are regulated and limited in order to maintain natural values.

Another forest conservation program is the METSO program in southern Finland. This program aims to increase voluntary-based conservation agreements between private forest owners and authorities. ${ }^{19}$ Through the program, a forest owner can offer his/her forest either for permanent or temporary protection. The economic compensation is estimated based on the lost stumpage revenues and is paid by the government. Apart from protection, the METSO program also includes possibilities for nature management in forest habitats. The program has been popular among private forest owners because of its bottom-up approach and because the program is a voluntary commitment.

In Finland there are seven UNESCO World Heritage sites (six are cultural sites and one is for nature protection). The Finnish World Heritage sites include e.g. the Fortress of Suomenlinna in Helsinki, wooden town in Old Rauma, Petäjävesi Old Church, The Verla Groundwood and Board Mill and Kvarken Archipelago.

\section{Regulations and restrictions}

Different conservation areas may have specific regulations, but the national legislation always sets the overall frame. Thus, the degree of restrictions to human use varies depending on the type of protection and it can vary among different sites. For example, in National Parks public access by feet is generally accepted to all parts of parks and berry picking is allowed, while camping may be allowed only in limited parts of the park. In Finland, public access and human activities are most restricted in the so-called strict nature reserves, which are in total 19 different sites in Finland. The purpose of these sites is to protect biodiversity values, but they can also have scientific and/or educational importance. In general, people are only allowed in specific designated paths or areas and without specific permit all other access is prohibited. However, there can be exceptions, thus allowing some limited use in specific parts also in strict nature reserves. Berry picking is for example prohibited in the Kevo Nature Reserve in the northern Finland but allowed for local residents in the more southern Koivusuo Nature Reserve.

In the voluntary forest conservation program METSO there are very strict ecological criteria that determine what kind of forest areas that are allowed to be included. The programme itself does not include major restrictions to the right of public access.

\footnotetext{
${ }^{18}$ Metsähallitus runs business activities while also fulfills many public administration duties.

${ }^{19}$ www.metsonpolku.fi
} 


\subsection{Denmark}

About $13 \%$ of Denmark's land area, and $18 \%$ of the country's marine area, is under a formal set of rules for nature protection. However one of the main schemes - the Natura 2000 - has been implemented so that it is only a third of the total Natura 2000 areas in Denmark that actually consists of habitat types in the habitat directive. Besides the Natura 2000 network, which is well known in all EU-member states, Denmark has a number of country specific rules for nature conservation, which all partly overlap with Natura $2000 .{ }^{20}$ In Natura 2000 areas in Denmark, the landowner is not allowed to destroy the values and will be compensated for the economic loss of this restriction. The landowner is not obliged to enhance the values. ${ }^{21}$

The most important form of protection is the general protection of specific nature types like moors, grassland, meadows, heathland, streams and lakes. Another important protection is the Danish version of nature reserves (called "fredninger"), where all sites are unique and can protect either biodiversity-, recreational-, landscapeor historical values (or a combination).

Most forest areas in Denmark (covering a total of $15 \%$ of the land area) are protected against agricultural use or urbanization, but the values for biodiversity or recreation are not widely protected. Only a few percent of the forest areas are covered by individual legally binding agreements with landowners or voluntarily protected (e.g. as part of a certification scheme).

\section{Regulations and restrictions}

In Denmark there are a few formal wildlife reserves, but here recreational use is strictly limited. A difference in Denmark compared to other Nordic countries is that the concept of the Danish national parks does not automatically restrict any use or does not even protect natural or cultural values. As a consequence, national parks are not included in the statistics over protected nature in Denmark. The national parks in Denmark are more like the UNESCO World Heritage concept in that sense that it does not give a formal protection. Voluntary agreements for protection of e.g. unmanaged forests are possible also in Denmark. ${ }^{22}$ The forest owner will receive compensation for protecting forest with high biodiversity values. The voluntary agreement does not result in any restrictions regarding access to the areas.

\footnotetext{
20 "Sådan ligger landet - tal om naturen 2016", Danmarks Naturfredningsforening, http://www.dn.dk/Default.aspx?ID=2689g http://svana.dk/natur/national-naturbeskyttelse/beskyttede-naturtyper3/beskyttelse-af-3-naturtyper/

${ }^{21} \mathrm{http}: / /$ svana.dk/natur/skovbrug/lovgivning/vejledning-om-skovloven/17/

22 http://svana.dk/natur/skovbrug/privat-skovdrift/tilskud-til-private-skove/
} 


\section{$2.4 \quad$ Norway}

The impact from different forms of land-use change is the major causes to biodiversity loss in Norway. Numbers show that approximately up to $87 \%$ of the species classified as threatened in Norway are so because of land-use change. ${ }^{23}$

The Nature Diversity Act is an important environmental legislation in Norway and the legislation covers the conservation of biological-, landscape- and geologicaldiversity. According to the Statistics Norway (2013) protected areas cover more than $95,250 \mathrm{~km}^{2}$ of the land, which is equivalent to $25 \%$ of the total area. National parks are covering a large part of the protected land and there are in total 44 national parks, of which 37 are on the mainland and 7 on Svalbard. ${ }^{24}$ The national parks cover a surface of over $30,000 \mathrm{~km}^{2}$ in the mainland and over $14,000 \mathrm{~km}^{2}$ in Svalbard and Jan Mayen. In addition to the national parks there are also a number of other protections such as for example landscape protected areas (covering approx. 17,000 km²) and nature reserves (covering approx. $48,000 \mathrm{~km}^{2}$ ). ${ }^{25}$

Cultural heritage is protected specifically by protected cultural areas (covering approx. $200 \mathrm{~km}^{2}$ ) and protected cultural environments (covering approx. $54 \mathrm{~km}^{2}$ ). There are eight World Heritage Sites in Norway, of which seven of them are cultural sites. ${ }^{26}$ The Norwegian Parliament adopted national objectives for the management of the cultural heritage in 2005. As a consequence, ten conservation programmes were given high priority by the Ministry of Climate and Environment and the Directorate for Cultural Heritage. ${ }^{27,28}$

\section{Regulations and restrictions}

National parks are in general open to visitors but there are areas where there are more strict restrictions. These are especially vulnerable areas, both national parks and nature reserves, where e.g. paths and accommodation possibilities are limited in order to minimize the impact on the wildlife from e.g. tourism. ${ }^{29}$ For example, the Unesco World heritage site Vega Archipelago, is strictly regulated to ensure the protection cultural areas, as well as flora and fauna with a specific emphasis on protection of birds during the breeding season. ${ }^{30}$ There are also places within the Eastern Svalbard reserve where there are entrance prohibitions to some cultural heritage sites within the nature reserves. Many cruises travel in this region, thus, regulations can have impact their

\footnotetext{
23 http://www.environment.no/topics/biodiversity/

24 https://www.visitnorway.se/aktiviteter/naturupplevelser-i-norge/nationalparker/

25 https://www.ssb.no/en/natur-og-miljo/statistikker/arealvern/aar/2014-11-03

${ }^{26}$ http://whc.unesco.org/en/list/\&order=country\#alphaN

${ }^{27}$ Programs include private owned protected buildings, Sami cultural remains, the mediaeval stave churches, Norwegian

World Heritage, technical and industrial heritage, fire safety on wooden towns and environments, historic vessels, ruins, rock art and archaeological heritage.

${ }^{28}$ http://www.herein-system.eu/norway-country-profile

29 https://www.visitnorway.com/things-to-do/nature-attractions/national-parks/

$3^{30} \mathrm{http}: / /$ whc.unesco.org/en/list/1143
} 
activities with the purpose to ensure that the tourism in the region does not have an impact on natural or cultural heritage..$^{31}$

\subsection{Iceland}

In Iceland there are five different categories of conservation; national parks, nature reserves, country parks, monuments, and other conservation areas..$^{32}$ Nature in Iceland differs significantly from nature in other Nordic countries. For example, forests cover only $0.3 \%$ of the total area, only $2.4 \%$ of land is arable and a significant part of the country suffers from acute soil erosion. Legal designations and restrictions differ between different protected areas. ${ }^{33}$ National parks are established because of valuable landscape, flora or fauna, or special historic significance. Nature reserves are established in areas considered important of their landscape, flora or fauna. There are 13 so-called country parks that are primarily intended for recreational purposes and managed by the local government.

According to OECD (2014), about $20 \%$ of the total area in Iceland is under some form of nature protection, which together with Norway is among the highest shares in the OECD. There are three national parks which add up to over half the total protected area. ${ }^{34}$ Vatnajökull National Park is the largest national park and it covers about $12 \%$ of the area of Iceland. ${ }^{35}$ The park is mostly covered by the Vatnajökull glacier. ${ }^{36}$ In Iceland there are two World Heritage Sites: Pingvellir and a volcanic island, Surtsey. ${ }^{37}$ Pingvellir (Thingvellir) is the National Park where the Althing, an open-air assembly representing the whole of Iceland, was established in year 930 and where they continued to meet until 1798.

\section{Regulations and restrictions}

As in the other Nordic countries restrictions in Iceland's protected areas can vary depending on the purpose of the protection. ${ }^{38}$ In nature reserves and national parks where wildlife and landscape values are being protected different types of restrictions on e.g. development and limitation to public access can occur. The degree of the restriction may vary between different sites. Country parks on the other hand are established solely for recreational purposes. There can however be specific regulations also in the country parks but they are not as strict as in for example national parks or nature reserves. One common regulation is for example prohibition of unnecessary construction works.

\footnotetext{
$3^{11}$ http://www.aeco.no/2014/04/new-regulations-eastern-svalbard-nature-reserves/

${ }^{32}$ www.ust.is/the-environment-agency-of-iceland

33 OECD 2014.

34 OECD 2014

35 www.ust.is, Statistics Iceland 2016

$3^{6}$ OECD (2014), OECD Environmental Performance Reviews: Iceland 2014, OECD Publishing.

http://dx.doi.org/10.1787/9789264214200-en. Statistics Iceland 2016. http://statice.is/statistics/environment/geographical-data/

$37 \mathrm{http}: / /$ whc.unesco.org/en/statesparties/is

${ }^{8} \mathrm{http}: / /$ www.ust.is/the-environment-agency-of-iceland/protected-areas/
} 



\section{On measuring value from natural \& cultural heritage}

This section describes how economics can help highlight values generated by natural and cultural heritage and thus improve decision-making related to natural and cultural heritage. Section 3.1 discusses the need for welfare economics and describes how economists think about, and measure, economic value in order to improve human wellbeing and reach sustainable development. Section 3.2 provides another way of using economics to measure values generated by the market. Importantly, these are different types of values, but both may be relevant for decision-makers.

\subsection{Welfare economics}

In a world of scarce resources for protecting our natural and cultural heritage, welfare economics provides tools to help to balance benefits and costs of alternative policies in order to maximize human well-being over time. This is nearly identical to the goal of achieving sustainability, i.e., "meeting the needs of the present generation without compromising the ability of future generations to meet their own needs" (Brundtland Report 1987).

One way of defining and expressing sustainability is to consider well-being across three spheres: ecology, social, economic (e.g. Agenda 21, 1992). Ecology refers to ensuring a resilient plant and animal kingdom; social refers to well-being of humans and their relationships on the planet; and economic refers to a well-functioning system that provides opportunities for trade and betterment of the population.

Welfare economics addresses both the social, ecological and economic aspects of sustainability by assessing the net impacts on our well-being from investments we make in our own social, physical, and natural capital. It helps to address conflicts that may arise when different groups hold different values for a potential policy outcome. The primary contribution of welfare economics is to provide a framework for comparing the values generated from policy scenario 1 (e.g., protecting a resource) to the values generated from policy scenario 2 (e.g. consuming a resource). An important concept is opportunity costs, or the value foregone when a given alternative is undertaken: e.g., the cost of choosing scenario 1 over scenario 2. If we protect a resource today, the opportunity cost is the value that would have been generated had we consumed it instead. Alternatively, if we choose to consume a resource today, the opportunity cost is the value that would have been generated from protecting it. 
Rather than focusing on market indicators of value (as in section 3.2), this section addresses 4 key questions:

- What is a welfare economic value and must it provide benefits to humans?

- What types of (instrumental) welfare values exist?

- How do we measure these values?

- Which values are relevant to natural and cultural assets?

\subsubsection{What is economic value?}

What an individual considers to have value - i.e., what improves his/her well-being varies from person to person. Value can be affected by a person's material, spiritual or moral attitudes and may differ between experts from different disciplines such as ecology, economics, psychology and philosophy. But on a fundamental level, value can be divided into two categories (Freeman et al., 2014):

- Intrinsic value. An environmental or cultural good or service may have value in and of itself, completely independent of any benefit (direct or indirect) it may provide humans.

- Instrumental value. A good or service may be valued as a means to reach a specific human-focused end, such as good health, safety, satisfaction or happiness. Instrumental values do not exist in a world without humans, as it is the human valuation that defines this value.

In this report we focus solely on the instrumental values generated by natural and cultural heritage, as we assume that values that generate benefits for humans are the only relevant values for decision-makers. For example, we assume that the conservation of historical sites, wetlands, and/or species is motivated by the contribution this makes to individuals' well-being.

\subsubsection{What types of (instrumental) welfare values exist?}

The Total Economic Value (TEV) framework (see e.g. Pearce and Turner 1991, de Groot et al. 2002, de Groot 2006 and Balmford et al. 2008,) shows all instrumental values that an ecosystem or cultural area generates, now and potentially in the future. The goods and services generated by an ecosystem or cultural landscape can create and contribute to people's welfare either by being used directly or indirectly (use value), but can also be valued even if it is not used (non-use value).

Figure 1 illustrates the categories of values included in the TEV concept. The use values are commonly divided into direct use value, indirect use value and option value. Direct use value is defined as goods and services that are directly consumed such as food, timber, fibre, water, but also aesthetic views, recreation possibilities and possibilities to perform research. Mitchell and Carson (1989) define use values as values 
that occur because people are physically affected by the resource in some way. Indirect use values are created by the benefits from secondary goods and services. This includes regulating services such as carbon storage that enables a stable climate and extraction of e.g. fish and soil quality that enables extraction of fuel and food. In addition to this, the goods and services can have an option value, i.e. the value people put on the opportunity to keep the possibility to use the good or service in the future, even though it is not used today.

Non-use values are divided into bequest value, altruistic value and existence value. Bequest value is the value people put on keeping a good or service for the coming generations. Altruistic value is the value people put on a good or service for the pleasure of others, while existence value is the value people put on the pure existence of a good or service even though they never use it, consume it or think that they will in the future. Finally, some consider the importance of insurance value, which captures the idea that diverse ecosystems are more resilient and may provide enhanced ecosystem services (see e.g. Pascual et al. 2015; Bartkowski 2016). Given that most individuals tend to be risk averse, the risk reduction valued can be a significant economic value generated by biodiversity.

Proper use of the TEV concept would consider and integrate each of these values generated by the ecosystem and/or by cultural landscapes into decision-making, which naturally must rely on different valuation techniques.

\subsubsection{How do we measure these values?}

There are several valuation techniques available for estimating monetary values for the types of non-market benefits described in Figures 2 and 3 . The studies presented in Appendices 1 and 2 rely on these methods to illustrate welfare values associated with natural and cultural heritage. Applying such methods is not straightforward, but a description of these methods and potential biases are beyond the scope of this study. More details on valuation techniques can be found in e.g. Freeman et al (2014) and also in a previous report published by the Nordic Council of Ministers, Barton et al., 2011.

\subsubsection{Which Total Economic Values (TEV) are relevant to natural and cultural heritage assets?}

The TEV concept provides a useful starting point for characterizing relevant economic values. The figures below link the TEV value categories to specific types of economic benefits that drive the conservation of natural and cultural heritage, namely biodiversity (Figure 2) and landscape/cultural heritage and outdoor recreation (Figure 3 ).

The purpose is to provide an analytic framework that links the broad and general categories of "use and non-use value" (including subcategories such as direct, indirect, existence, altruistic, insurance, etc.) to specific and concrete examples of economic goods derived from conserving natural and cultural heritage. This conceptual framework provides the background to Chapter 4.1 where we highlight the magnitude of (some of) the welfare values connected to these goods. 
In Figure 2 biodiversity produces two components of value: output value (including both use and non-use) and insurance value. Output value refers to the economic goods produced today or in the future from the tangible or intangible benefits of biodiversity, while insurance value captures the economic benefits from a resilient ecosystem that can better withstand fluctuation and disturbance and thus protect a future "user's income risk from using ecosystem services under uncertainty" (p. 14 Pascual et al. 2015).

Together, the figures demonstrate that both biodiversity (Figure 2) and landscape/cultural heritage and recreation (Figure 3) support use and non-use values, but biodiversity conservation is predominantly motivated by non-use values. For example, indirect and option values are strongly connected to protection of habitat and species diversity, while there is less direct value associated with biodiversity. Conversely, values associated with e.g. historic sites or recreational access points are quite often related to direct use, although there is a strong argument for protecting historic sites, even if they are not directly enjoyed by visitors.

Note that non-use values are by nature more difficult to assess, and thus less visible to decisions-makers. Some of the use values shown in the figures in Appendices 1 and 2 may also lead individuals to visit a site and spend money, leading to local income, jobs, and tax revenue. These economic benefits are thus translated into monetary values via the market, but these benefits represent only a portion of value generated.

Figure 2: Linking Total Economic Value (TEV) to the benefits provided by biodiversity (Value categories with thick borders indicate a greater relevance to that benefit type)

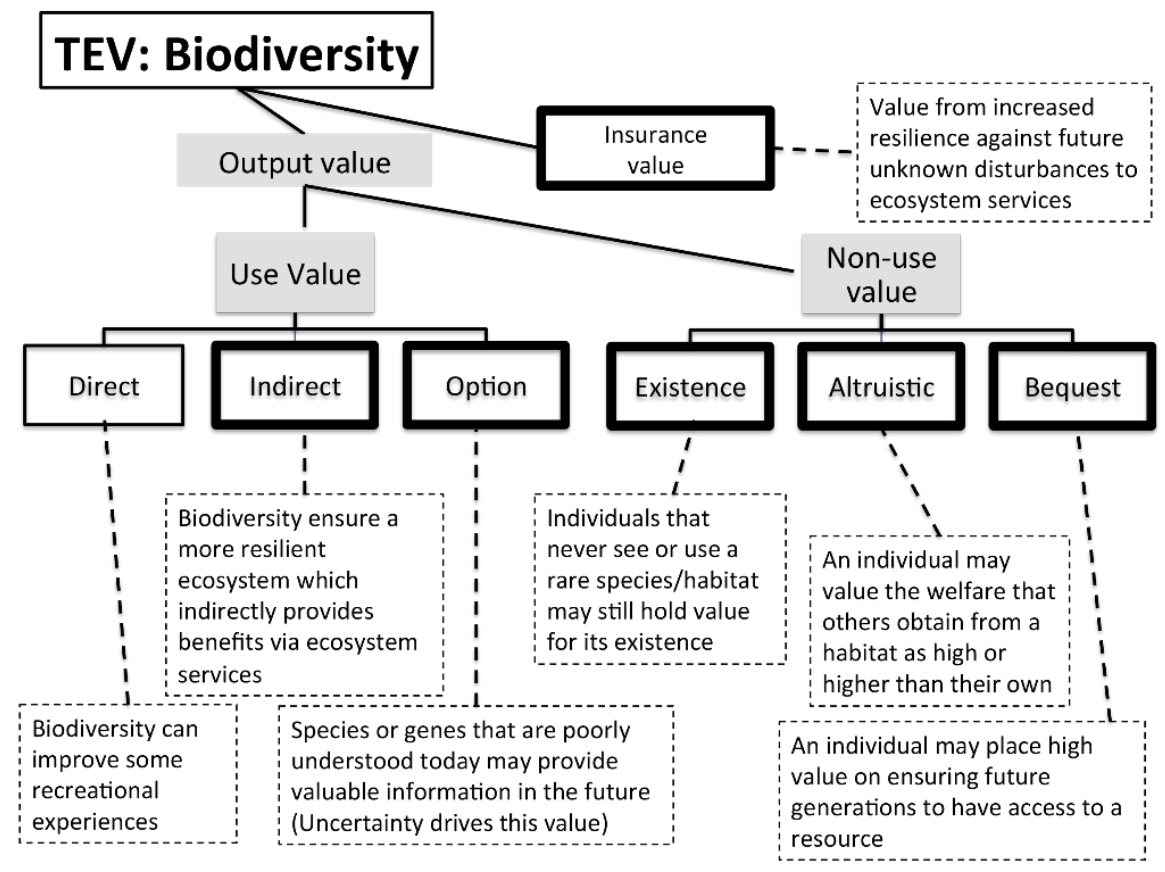




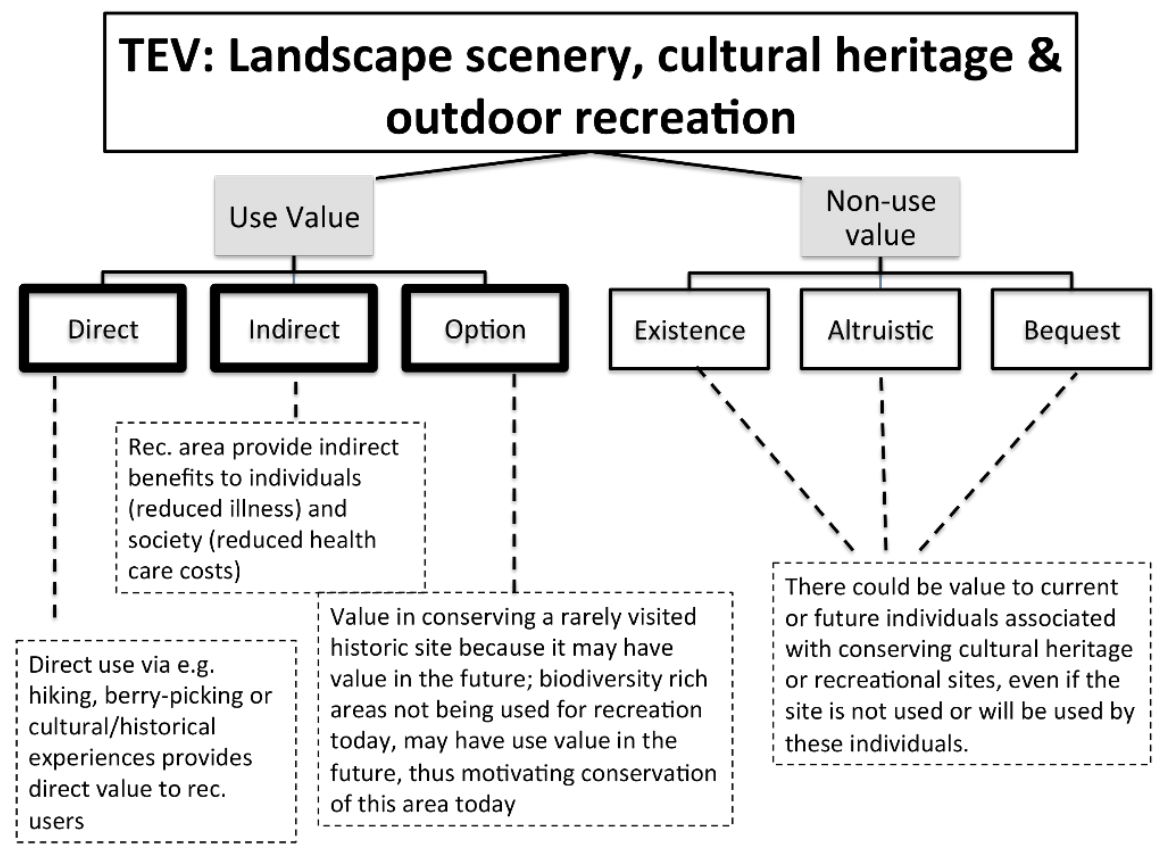

\subsection{Economic impact analysis}

An entirely separate, but also useful way to measure the economic importance of natural and cultural heritage is to focus exclusively on indicators from the markets. This type of economic impact analysis focuses on how a specific state of, or changes in, goods and services provided by natural and cultural heritage affects the economy in terms of income and job creation (direct and indirect), taxes and economic output. Economic impact analyses are commonly based on input-output models that capture the direct, indirect and induced impacts on a local economy.

In the case of forest conservation, the most obvious economic impacts are lost stumpage revenues and jobs in forestry. In addition, the forestry sector may face costs associated with wood scarcity and/or increased timber prices. This type of reduced economic activity may also have direct and indirect impacts at local or regional levels while large conservation programs may even have national level impacts. However, forest conservation may also lead to positive economic impacts such as increased nature-based tourism, which can lead to jobs e.g. in the service sector (e.g., hotels, restaurant, retail trade). These positive job and income effects can lead to increased consumption and thus in addition to direct, indirect and induced impacts.

Viewpoints of regional impact analysis and cost-benefit analysis are significantly different, but they can both provide useful information to decision makers. Economic 
impact analysis is based on the estimation of actual financial flows caused by certain activity and direct, indirect and induced impacts of the activity. The results from such an analysis can thus be of interest for decision makers for assessing impacts of different land-use options on the number of jobs or tax incomes in specific areas. However, this approach fails to capture non-marketed values, e.g. recreation or biodiversity values, and therefore provides only partial information about impacts on welfare (therefore it should not be seen as a substitute for TEV).

\subsection{Conclusion: Two ways to measure economic value}

Welfare economics can help assess the net outcome on welfare when comparing the benefits of protecting cultural and natural heritage to the costs of generating those benefits through legal or other conservation measures. Importantly, there are two alternative ways of measuring economic value - changes in individuals' welfare (see TEV) and changes in economic indicators (e.g., employment, income, production, tax revenue, etc.), where the latter represents only partial information about effects and does not provide a basis for comprehensive welfare decisions. 


\section{Economic welfare values from natural and cultural heritage}

This section presents a non-comprehensive selection of studies that illustrate the type and magnitude of economic welfare values from the literature for conserving natural and cultural assets and discusses how to balance these values against their opportunity costs via economic trade-offs. This information is critical for improving decision-making by accounting for economic well-being via Cost-Benefit Analysis (CBA).

To illustrate welfare values, we reviewed valuation studies that focus on the three benefits that drive the conservation of natural and cultural heritage: biodiversity, landscape scenery/cultural heritage and outdoor recreation. A list of selected studies, and their major outcomes, that covers landscape scenery/cultural heritage and outdoor recreation is presented in Appendix 1 while Appendix 2 covers values from biodiversity. The studies, which focus on Nordic countries, are illustrative rather than comprehensive, and thus capture some geographic diversity without necessarily assessing the distribution of valuation studies across countries. Furthermore the research setting, methods and timing of research differ and precludes comparison across studies.

\subsection{Literature summary: Economic values from landscape scenery, cultural heritage \& outdoor recreation}

Studies on welfare values for natural heritage areas that enable recreation are common in the international literature, while studies on landscape scenery and cultural heritage are scarcer. For example, Haefele et al. (2016) estimated the total economic value to the American public of national parks and found a welfare value of USD 92 billion, where two-thirds (USD 62 billion) were attributed to National Park lands, waters and historic areas. The estimate includes not only direct user value, but also captures visitors' "non-use" and "existence" value, i.e., "the value derived by the public from simply knowing that NPS assets are protected for current and future generations, regardless of whether or not they actually choose to visit." Reyes and Mates (2004) also estimate the welfare values derived from existing parks in New Jersey and compare them with the social costs of maintaining the parks, noting that they provide a significant net gain in welfare for state residents.

There are several studies in the Nordic countries that capture economic benefits (as categorized by the TEV framework) from recreation, but fewer studies that measure or value benefits from cultural heritage and the conservation of landscapes. However, recreation values and landscape values are often examined in the same study and it is not always easy to separate the benefits valued. In Appendix 1 we summarize 15 studies 
that examined different aspects of the TEV framework related to landscape preservation, recreation and cultural heritage. Seven of those focus on sites in Finland, three in Sweden, two in Norway and one in Denmark. Furthermore, one study focuses on national parks in Sweden, Denmark and Norway.

Even though valuation studies of cultural heritage are quite limited in the Nordic countries, e.g. Grammatikopoulou et al. (2012) and Hasund et al. (2011) assess landscape attributes in agricultural lands in Finland and Sweden, respectively. The studies show a significant willingness to pay for landscapes that support grazing animals and that ensure relatively larger "viewscapes" rather than small isolated grasslands. Furthermore, Bostedt \& Lundgren (2010) investigated Swedish citizens' valuation of the cultural heritage from the Sami reindeer industry and show a willingness to pay of approximately SEK 240 per household and year for sustaining the industry. When aggregated the total cultural benefits reached SEK 500-900 million annually.

For outdoor recreation the situation is different. There is extensive literature valuing different aspects of outdoor recreation - particularly in recent years - where many focus on valuing marginal changes in the quantity or quality of a recreational experience. For example, Tyrväinen et al. (2014) show that foreign and domestic tourists in northeastern Finland were willing to pay EUR 11-12 per visitor and week for access to a recreational area that is less impacted by intensive forestry operations. The study also showed that a reduction in forest trails would result in a welfare loss of EUR 10 per visitor and week.

Although problematic from a welfare economics perspective, some studies have nonetheless extrapolated marginal values in one location to estimate total values generated by a specific habitat (per ha) or national park (or Natura 2000 site) in another location. One example is Arcadis et al. (2011), which estimated the benefits from conservation measures aimed at the arctic fox and Lesser White fronted Geese in the Vindelfjällen Natura 2000 site. The study showed that the conservation measures would result in recreation/eco-tourism values of up to EUR 15 million for the period 2011-2030. Furthermore, Schägner et al. (2016) estimated the recreational values generated from national parks in Nordic countries and found that they generated as much as EUR 556 million (Denmark), EUR 15.5 million (Norway) and EUR 56 million (Sweden). The large difference in value was driven primarily by differences in the estimated total number of annual visits. Bue Bjørner \& Termansen (2014) estimated the recreational values generated from 2,475 major recreational sites in Denmark (e.g., forests, open areas, beaches) and found that the average site generated DKK 8,000 per ha (ranging from DKK 240$700,000 / \mathrm{ha}$. Consistent with economic theory, the highly valued sites were those closest to densely populated areas while the least-valued sites were those close to similar sites (i.e., the value of any given site decreases when users have nearby substitute sites from which to choose). 
Figure 4: Aestethic views are important benefits generated by the natural and cultural heritage and contributes to both welfare and economic impacts

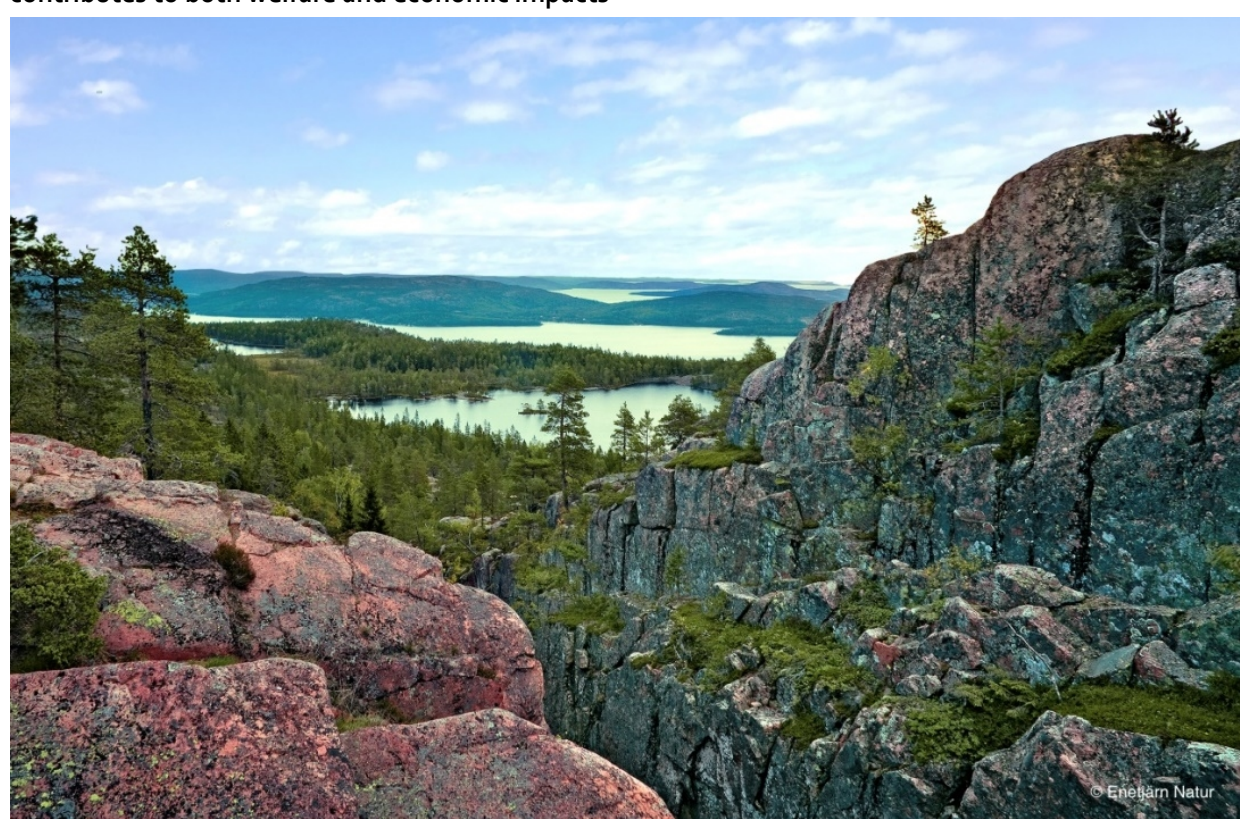

\subsection{Literature summary: Economic values from biodiversity}

The various regulations aimed at protecting habitats, flora and fauna suggest that biodiversity is highly valued by society. As discussed in Section 3.1.4, biodiversity contributes to human welfare through different types of economic values: use values (e.g., direct, indirect, and option), non-use values (e.g., existence, altruistic and bequest), and insurance value.

Several international studies have attempted to value the specific aspects of TEV that biodiversity from natural and cultural heritage sites generates. For example, Jobsvogt et al. (2014) estimated the option values and existence values of protecting deep-sea biodiversity and found a willingness to pay (WTP) of GBP 70/household and year for the option value of preserving biodiversity and a WTP of GBP $35 /$ household and year for the existence value of the species.

As it is not always relevant to in detail try to isolate different value categories of the total economic value of the resource, the specific value category in many of the studies presented in our appendices may not be determined or captured. This does, however not suggest that such values do not exist; but rather that they are sometimes hard to estimate in monetary terms using currently available economic valuation methods. Nevertheless, to understand what category of value that a resource generates might provide important information to land managers regarding policies such as preservation, restoration or ecological compensation.

Houghner et al. (2005) valued the seed dispersal by Eurasian Jays using the replacement cost method. The bird species' seed dispersal services for oak trees in 
Stockholm National Urban Park can be considered an indirect use value. The study found that a pair of Jays can provide a value of SEK (2005) 35,000-160,000. The study did not consider other aspects of the TEV that the species might generate, which implies that the total economic value of the species is larger.

Many of the available studies estimates the total value individuals hold for implementing a conservation measure that improves or prevents negative effects on biodiversity - some of which may focus on a specific species or habitat. Nikodinoska et al. (2015) estimated tourists WTP for activities that would mitigate effects from climate change on ecosystem services in Abisko National Park, Sweden. One interesting finding was that the respondents expressed a marginally higher WTP for supporting and regulating services than for provisioning and cultural services. This might imply a higher value for indirect use, non-use and insurance values relative to direct use values.

Furthermore, Lienhoop \& MacMillan (2007) investigated welfare impacts from reducing wilderness (lost flora and fauna, landscape and cultural heritage) resulting from development of hydropower in eastern Iceland. The study valued this loss by measuring what respondents required in term of compensation payments to accept this development, which was approximately ISK 780,000 (2007) per household and year. Bredahl and Jacobsen (2011) focused on capturing WTP for endangered species in three different habitats, forests, open fields and along lakes and streams, and found that people can be separated into different groups depending on their valuation of biodiversity. One group expressed a significant WTP for saving endangered species, but did not show a positive WTP for higher populations numbers of the species, which implies that the value is mainly driven by non-use values and insurance values. However, a second group expressed significant WTP:s both for increasing the population of endangered species and also for non-endangered species which suggest that people value biodiversity even though their function in generating certain ecosystem services is not explicitly recognized or if they are threatened to go extinct. These valuation might be driven by the fact that people hold existence values even for levels above critical, and that people expect that higher levels of biodiversity increases resilience and ecosystem functioning.

None of the Nordic studies we reviewed explicitly state that they aim to capture solely option or insurance value. Option and insurance values may nonetheless be substantial and may represent a significant portion of the TEV for biodiversity. 
Figure 5: Natural heritage are important for sustaining and promoting biodiversity that generate large economic use, non-use and insurance values

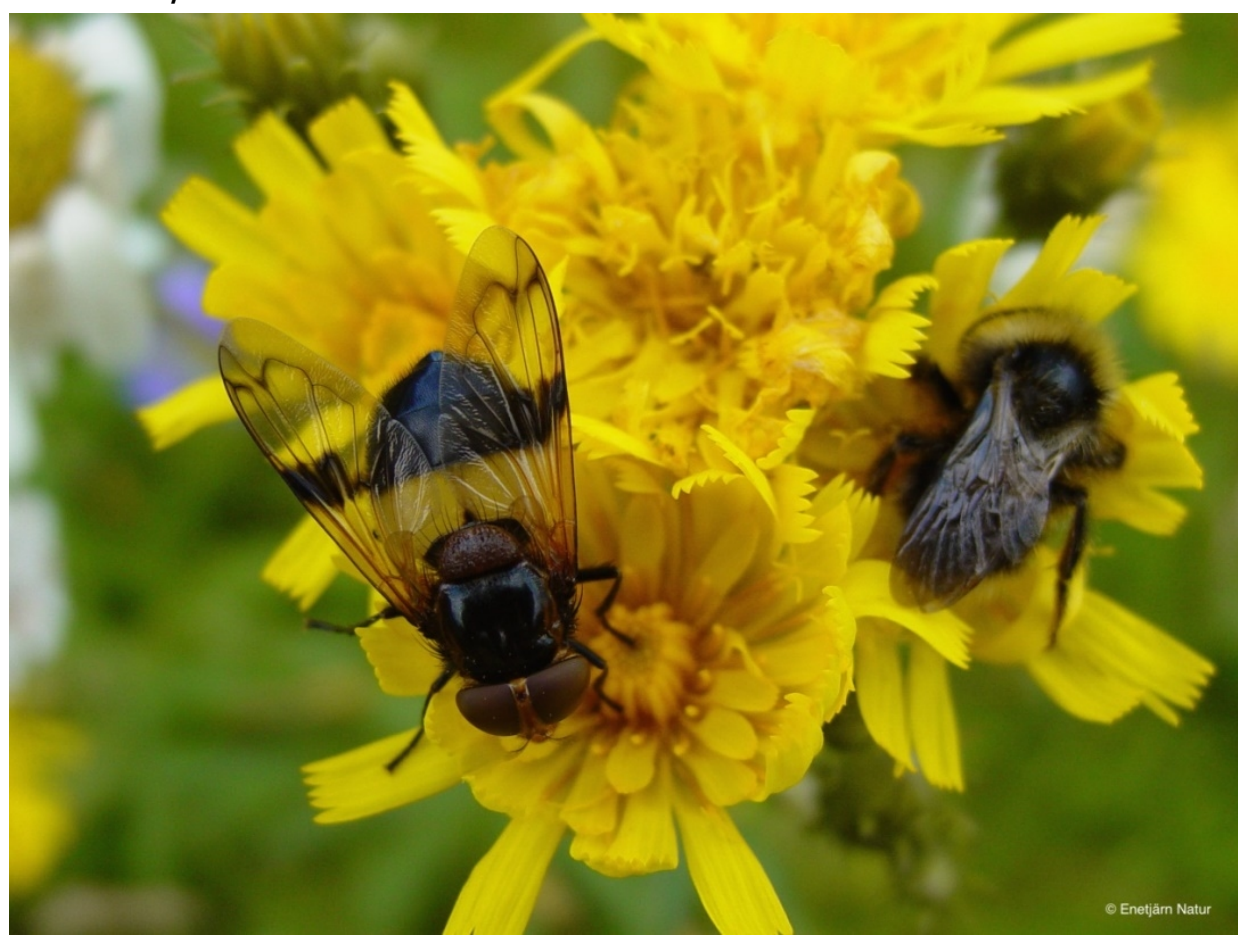

\subsection{Evaluating key trade-offs}

The economic values discussed above (and summarized in Appendices 1 and 2) often come in conflict with each other, which requires that policy makers consider and assess trade-offs. For example, the recreational values generated by improving access to forests may actually decrease the biodiversity values associated with certain forest habitats or species. We discuss three types of key trade-offs below, focusing on how welfare can be assessed under alternative scenarios and how this information can help formulate alternative policies to reduce conflict and improve the type and magnitude of economic values generated from conservation measures.

\subsubsection{Trade-offs between conservation and recreational or extraction use}

A common conflict is between direct use of resources such as extraction and recreation versus in situ conservation to protect biodiversity. Large shares of the Nordic countries cultural and natural heritage sites are under increasing pressure to accommodate a growing demand for housing, infrastructure, mines, etc. Regarding protected natural and cultural heritage areas, one of the largest pressures comes from recreational demands as activities become more commercialized and attract more participants (Jones et al. 2016; Naturvårdsverket, 2015). As discussed in the previous section, recreational activities are highly valued by the people in the Nordic countries, as well as by tourists. It thus 
contributes to the welfare of both the citizens and international tourists, at the same time as it enables income generation for companies in the Nordic countries. On the other hand, the different values that biodiversity generates are also highly valued by people (as shown in Ch.4.2. and Appendix 2). For example, in Oulanka National Park in Finland, the increase of biodiversity was the most highly valued feature by the national park visitors (Juutinen et al. 2013). Several Nordic and international studies demonstrate that conflicts may arise between biodiversity and outdoor recreation. Species and habitats can be affected by allowing human recreation and tourism through damage from clearing of vegetation and trampling (Pickering \& Hill, 2007), motorized recreation (Jones et al. 2016) and mountain biking and horse riding (Pickering et al. 2010). The goal is to balance the welfare of recreational users against the non-use values associated with conservation - some of which are yet unknown - that accrue to both current and future generations. Furthermore, one has to find balance between current and future recreation use. This can be quite a challenging task. Recreational activities are primarily valued by the actual users, who often assign high values for their possibilities to perform their activities. On the other hand, non-use values or insurance values from biodiversity might not be as highly valued per person, but as these values accrue to a larger population (an entire country or the whole world) the total value can be substantial.

Several studies suggest that managers of natural and cultural heritage sites should analyze what types of values that are at stake, and manage for several types of value (see e.g. Fredman \& Yuan 2011; Pickering \& Hill, 2007). Kniivilä (2006) examined the value held by users and non-users of conservation areas in Eastern Finland and found that non-use values are significant motives for valuing conservation areas even for those who use areas often.

If the conflict between recreation/extraction and preserved biodiversity is not properly addressed, the acceptance for protection or preservation of natural and cultural heritage sites might decline. For example, Zachrisson et al. (2006) showed that prohibiting or the threat of prohibiting certain activities might obstruct the establishment of new protections of natural and cultural heritage sites as the acceptance from locals might decrease (case of Kiruna National Park, threats from not allowing snow mobiling, fishing and hunting).

The trade-off between protecting species and habitats and allowing human use can be addressed by specific methods that are focusing on management for specific values. For example, land managers may optimize use and non-use values in a protected area by creating a plan that supports both biodiversity preservation goals and recreational demand, but in different areas. One example is the case of Fulufjället in Sweden, where managers used "zoning" as a method to assess trade-offs between values connected to outdoor recreation, nature tourism and biodiversity protection. ${ }^{39}$ Areas where assigned different levels of activity allowance, including untouched zones, low active zones, high active zones and facility zones. This implied that some areas were designated for pure conservation, other for quiet recreation and others for noisy recreation such as

39 In Swedish "Zonering". 
snowmobiling. Zoning does not however allow too large effects on species and habitats, as the land manager base the allowances in the specific zones on the biological protection purpose of the area. Economic valuation studies showing the value associated with each type of management area could contribute to optimize the management and thus find a balance between these trade-offs and maximize welfare.

Figure 6: The natural heritage promote outdoor recreation, an important benefit that create value both by increasing welfare but also as a means to create employment and income

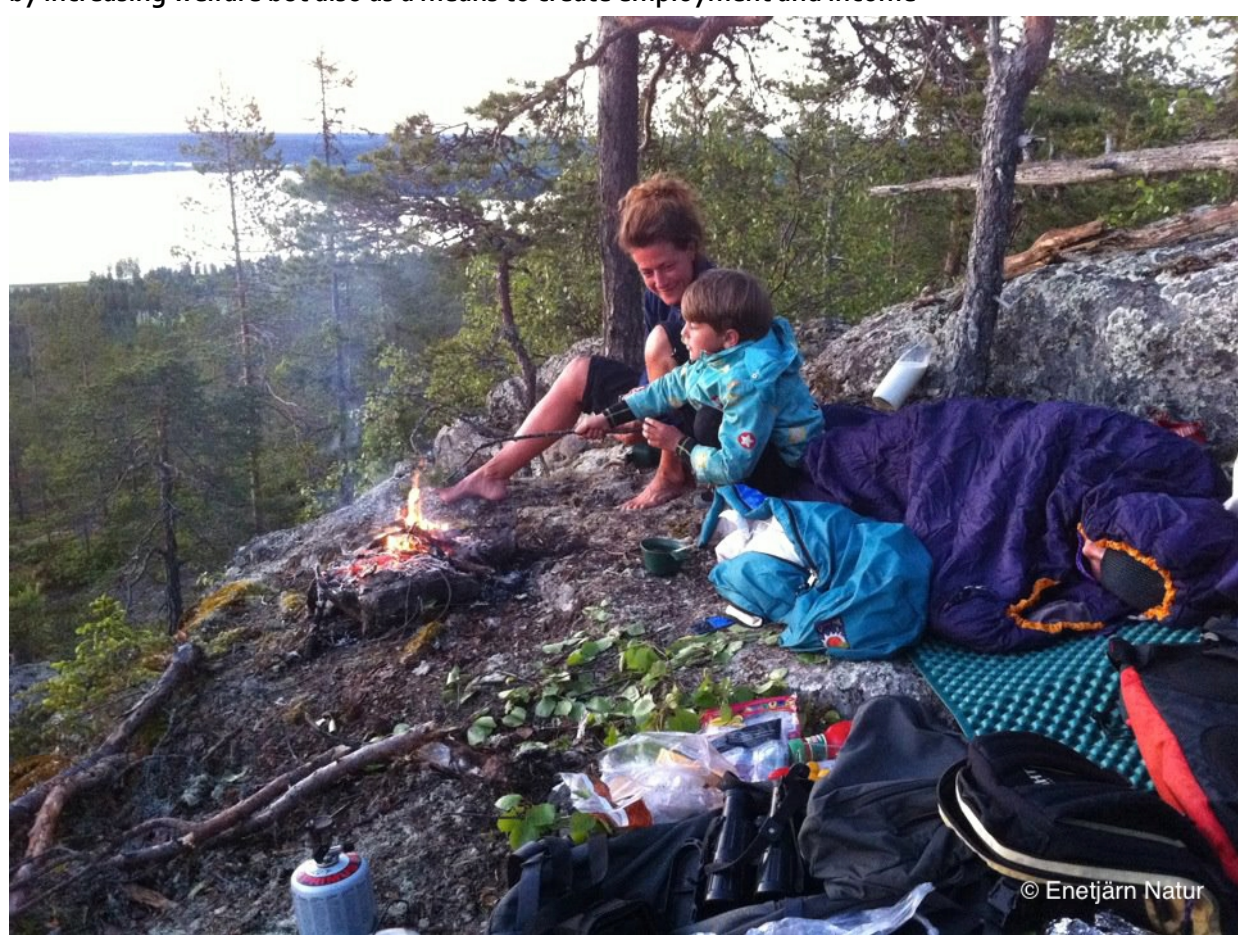

In addition to recreational use conflicts, conservation can also conflict with resource extraction. Even though extraction activities often is limited in protected natural and cultural heritage areas, such activities are occasionally allowed. This conflict is more evident when new conservation areas are created. Again, welfare economics can provide information about the distributional effects - i.e., who wins and who loses - and thus develop or design alternative policies (such as compensation) to improve or optimize management. Existence and establishment of forest conservation areas have created disputes e.g. in Finland, driven mostly by distributional effects. Kniivilä et al. (2004) found that for local residents in the municipality of llomantsi, the costs of existing conservation exceeded the benefits created. However, the benefits of conservation to non-locals exceeded the costs. This type of scenario, which is not uncommon in Nordic areas, can be addressed through compensation payments "from winners to losers." Theoretically, a net gain could be generated if non-locals provide a "payment" to locals, which could take the form of higher entrance fees for non-locals, a payment for ecosystem services program, differentiation of tax payments or financial support from the government. 
Figure 7: Large parts of the Nordic countries are covered by forests that generate a variety of ecosystem services such as timber, cultural values, recreation and biodiversity

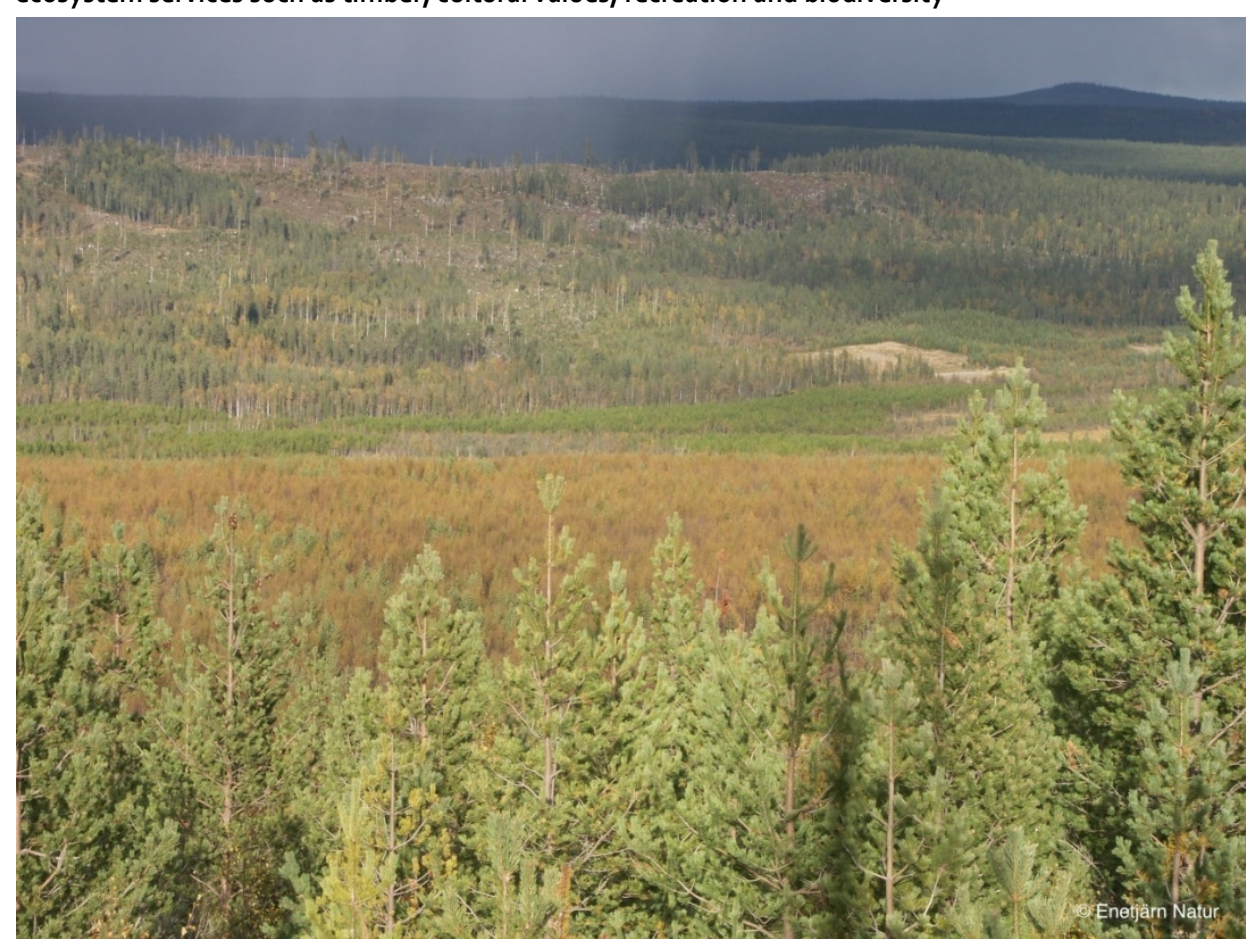

\subsubsection{Trade-offs between recreational values}

Conflicts may also arise within different types of recreational activities and between recreational user groups, where the management of a resource may affect which groups benefit most from a resource. Preferences vary among users when it comes to site attributes. Wall Reinus (2007) showed that some of the most important attributes in a natural and cultural heritage area were no litter, silence and peacefulness, tranquility, and avoidance of crowding. Many of these attributes might be affected by the total number of recreationalists and/or by certain activities like snowmobiling, boating, hunting etc. (see e.g. Collins, 2011).

Due to varying preferences, some user groups may attach very different values to the same resource. Coupal et al. (2001) showed that snowmobilers in the US have a WTP ranging from USD 12-49 per trip. On the other hand different studies (see Appendix 2) show that other groups have a willingness to pay to experience "quiet" activities like cross-country skiing (Saelen \& Ericsson 2013), walking/hiking in forest or urban green area (Tyrväinen et al. 2014, Juutinen et al. 2011), berry and mushroom picking, etc. Importantly, some users are willing to pay more for their activity to avoid factors that may diminish their experience, such as noise or crowding. For example, Swedish cross-country skiers were in 2005 willing to pay SEK 50 per day to avoid sharing tracks with snowmobilers and SEK 70 per day for snowmobilers to not be allowed in the areas (Lindberg \& Fredman 2005). One study even suggests philosophical conflicts between user groups, meaning that competition-related use, such as adventure racing, 
is not compatible with passive appreciation of conservation values (Newsome, 2014). This suggests that limiting a noisy activity will decrease value for one user group, while increasing values for another.

Another potential conflict is between hunting and wildlife watching. Both provide different value to different groups, but are not necessarily incompatible as long as they are done at different seasons or in different areas. Both activities contribute to welfare values through the recreational experience, but hunting can provide relatively larger contribution to local economic impacts due to higher expenditures (see Section 5).

A similar problem is the trade-off between quantity and quality. Marketing of a natural heritage resource may increase total visitorship (and thus stimulate positive economic impacts), but the experience of each individual (the per trip value) may decrease as more users appear on site.

In short, any policy alternative presents an opportunity cost to managers of natural and cultural heritage sites. Economics can help support multiple use management. The fact that some users are willing to pay more to obtain a certain experience provides room for managers to defend a specific policy or restrict certain activities (e.g., reduce crowding or noise) and thus meet the needs of multiple users. But managing for these multiple uses requires information on what attributes are valued by different groups, and how much they value them.

Figure 8: The natural and cultural heritage enables recreational activities such as hiking, which can improve welfare, health and knowledge about our natural environment

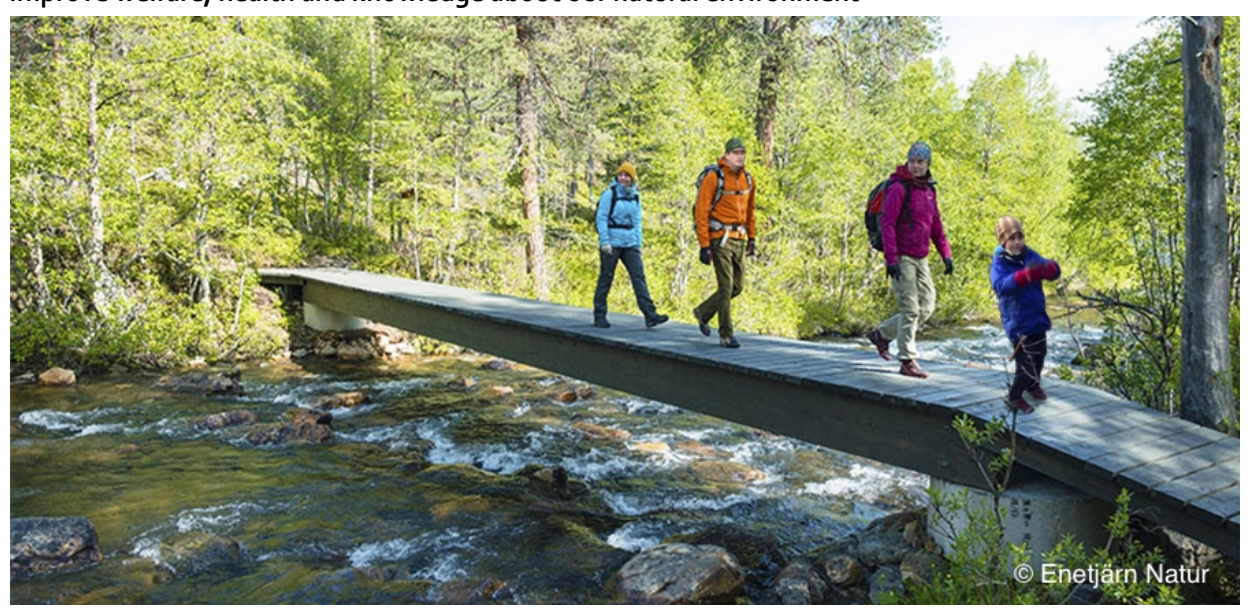

\subsubsection{Trade-offs between biodiversity values}

Regulations designed to protect natural and cultural heritage sites may also protect biodiversity, but measures to improve one habitat type may come at the costs of another habitat type. These types of conflicts require environmental managers to make a choice, as both habitats cannot be protected simultaneously. In these cases, economics can help identify the different types and magnitude of values at stake and inform better management. 
There are several examples of these types of conflicts. Some management plans may call for natural recovery (i.e., prohibition on active restoration measures), but these prescriptions may lead to the decline of other habitats/species that have evolved after centuries of human activity. Some nature reserves prohibit certain human activities (e.g., physical damage from walking, cycling, driving, etc.) in order to protect a habitat type, but these types of activities might actual assist in creating habitats for certain species. This type of approach creates a clear threat against existing species, but revising the management plan to aid these species works against the re-establishment of species that were found prior to human interference. Furthermore, such policies might hinder activities that actually are positive for biodiversity, such as removing invasive species, etc.

Land managers are currently going through a transition from a strict focus on "natural recovery" to approaches that allow more flexibility based on human preferences: i.e., what do we want our landscapes to look like in the future? This new management approach requires information on how alternative biodiversity measures produce varying ecological effects, which can be valued with the help of the TEV framework. For example, we could select biodiversity conservation measures that contribute to the types of values we think are most important. For example, should we focus on generating direct use values (e.g., species that benefit wildlife viewing or bird watching) or indirect user values (e.g., species that provide an important ecological function that ultimately provides valuable ecosystem services) or existence, bequest and altruistic values (e.g., species characterized as the "large charismatic megafauna"). Another approach is to protect species that provide some type of ecological function that we do not fully understand today based on the fact that they provide insurance and/or option value. Further, species that provide us with option value can, in theory, be protected anywhere on earth, while species that provide direct or indirect user value should be protected in specific areas, where they provide the most benefit. These types of decisions can be made when we know more about the type and magnitude of values at stake. Further, these economic concepts can help us maximize economic welfare, given society's limited resources to protect biodiversity.

The challenge of course is in applying economic methods and concepts in practice given our incomplete understanding of how changes in ecosystem function affect our well-being (i.e., what are the welfare implications when a species goes extinct?). But environmental economic concepts can nonetheless help to structure and support decision-making. For example, economic arguments support the application of the precautionary principle, the fact that we value resilience in ecosystems (ensuring more certain delivery of ecosystem services in the future) indicates that insurance and option value components of the TEV framework are critical when discussing biodiversity values. But the challenge remains, we must improve the ecological and economic parameters in our interdisciplinary models if we wish to support socially optimal decision-making. 
Figure 9: Reindeer herding and the Sami culture is one of the most important cultural heritages of the Nordic countries. The value created is larger than the economic impacts from this sector

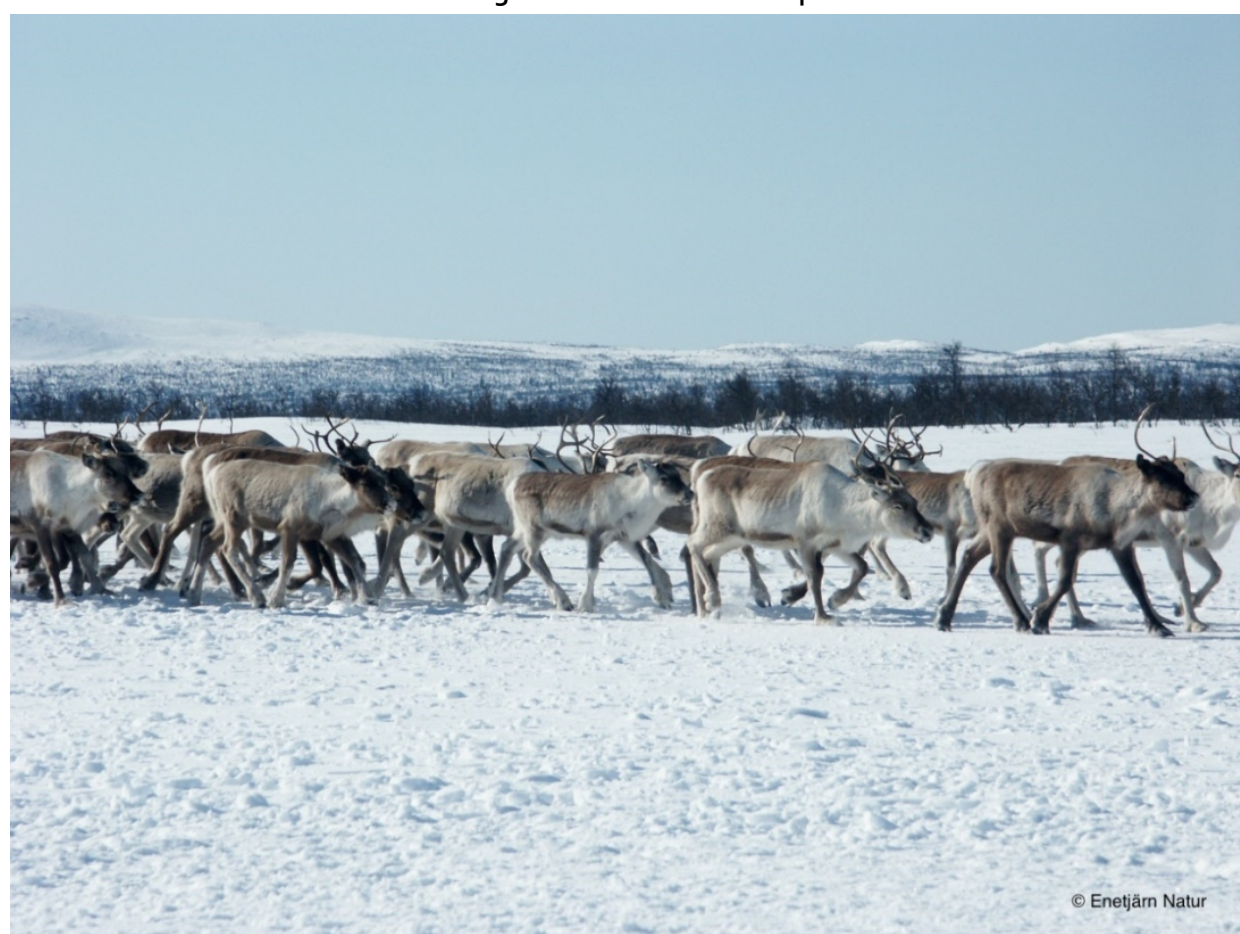





\section{Economic impacts from natural and cultural heritage}

This section presents a non-comprehensive selection of studies that illustrate marketbased benefits known as economic impacts and discusses policy implications that may arise from these types of analyses. These benefits may include direct impacts on employment, income, production, tax revenue as well as indirect and induced impacts that may follow. Information about the flow of money (or other market-based indicators) from one region to another helps decision-makers better understand the regional development implications of alternative land use. Importantly, market-based benefits capture only a portion of economic welfare and thus cannot be relied upon to assess overall welfare impacts as with Cost Benefit Analyses (see section 4).

\subsection{Literature summary: economic impact analysis}

To illustrate economic impacts we review studies that capture various market-based impacts: jobs created/lost, income generated/lost, money spent (e.g., per person or per recreational trip) or even tax revenue generated. The variation in study context and design makes it difficult to compare studies from different countries and/or sites. Thus, study results should be interpreted on a case by case basis. The studies, which focus on Nordic countries, are illustrative rather than comprehensive.

Economic impact studies related to the protection of natural and cultural heritage are common outside Nordic countries. For example, Thomas and Kontz (2015) estimate that the 300 million annual visitors to US National Park System generate significant market-based values: expenditures alone reach USD 17 billion when receipts from nearby areas are included. This results in jobs, labor income, value-added and economic output. These types of studies are often used on a local level to motivate the establishment of a new national park (Powers, 2001; Headwaters Economic 2012) or national wildlife refuge (Unsworth and Paterson 1999), where the later study even considered the net effect on local tax revenues.

While economic impacts have been examined in all Nordic countries, such analyses are particularly prominent in Finland, where they are carried out systematically in national parks and outdoor recreation areas owned by the state and managed by Metsähallitus..$^{40}$ To our knowledge similar comprehensive investigations do not exist in the other Nordic countries, which is evidenced by the geographic distribution of the studies we summarize below. Appendix 3 contains details of ten selected studies: Five 
studies focus on Finland, three on Sweden and one each from Denmark and Norway. We identify a few highlights in the text below.

Results from several Finnish studies suggest that investment in conservation results in social profits. For example, the economic impacts from Finland's 39 national parks are estimated at EUR 141.5 million and 1,400 jobs (full-time equivalent) in 2015. Similarly, the 6 hiking areas were valued at EUR 12.2 million and generated 131 jobs (FTE)..$^{41}$ According to Metsähallitus, investment of one euro of taxpayers' money in the hiking services of national parks leads to a benefit to the local economy valued at EUR 10, on average. For national parks located near ski resorts, the average input-output ratio is even higher, 14 to 1 . Importantly, these ratios do not consider alternative land use, i.e., they suggest that conservation provides seemingly high returns, but they do not quantify the potential economic return on alternative investments.

Very few studies have investigated economic impacts from conservation measures in Sweden, Norway, Denmark and Iceland and those that exist in Sweden, Norway and Denmark are generally less comprehensive than those in Finland and in general performed on a case by case rather than systematic basis. However, Bowits \& Ibenholts 2009 estimated the economic effects from cultural heritage tourist visits to Røros, Norway, and showed that 200 jobs were created (both direct and indirect), which was approximately $7 \%$ of the city's workforce. Fredman and Yuan (2011) investigated tourism expenditures and found that Germans spend on average SEK 1,860 per trip when visiting Fulufjället National Park, while Swedes spend SEK 780 per trip. Moreover, the expenditure of foreign tourists include purchases made "en route" to the destination, which implies significant economic impacts in and around gateway communities.

${ }^{41}$ http://www.metsa.fi/web/en/economicbenefitsofnationalparks 
Figure 10: The protection of natural and cultural landscapes enable both present and coming generations to enjoy beautiful views and nature experiences

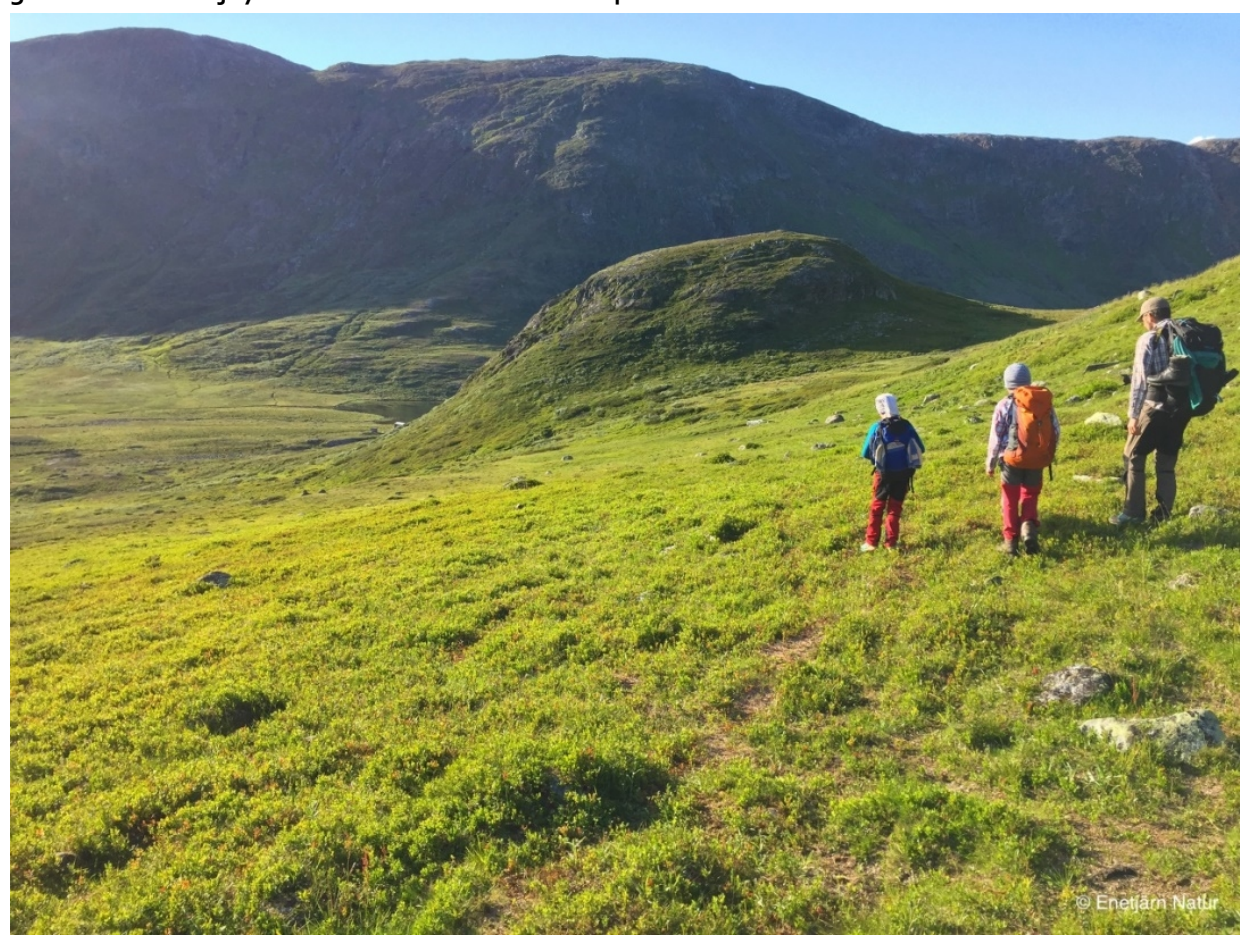

\subsection{Policy implications}

Even if a certain conservation measure has little impact on net welfare, i.e., economic values generated are small relative to the opportunity costs, it may nonetheless have local economic impacts. An economic impact analysis, like the ones summarized in Appendix 3 , can help identify and measure these impacts which, in turn, can help address policy issues such as how to maximize job creation, improve regional productivity, increase tax revenues or design policy to offset negative impacts that may arise from conservation. We address several key questions in this respect:

- What factors influence the size of economic impacts - what creates jobs and income locally?

- Can the design of conservation measures or policies help stimulate positive economic impacts?

- Given that conservation costs money, how can local financial flows help finance such measures? 


\subsubsection{What factors influence the size of economic impacts?}

The key variable driving positive economic impacts from conservation is the number of visitors to a site (Vatanen et al. 2014), but other factors can affect whether a site actually produces economic benefits. The key question is whether there is visitor demand and whether this demand can be met by a local economy. Importantly, the benefits and costs of alternative land-use options should be considered before trying to stimulate economic impacts via conservation measures.

Given a focus on conservation in an area, the following factors can influence visitorship and thus economic impacts:

- Location of site (sites close to urban areas attract more visitors).

- Services offered (recreational attributes like hiking trails, access for motorized recreation etc.).

- Environmental attributes (scenery, historic buildings, water quality, etc.).

- Cost of access (travel costs, possible fees to enter a park).

- Designation status (national park's send a signal of higher value relative to other natural and cultural heritage areas).

- Complementary sites or attractions in the vicinity (provides multiple site visits per trip).

Visitor numbers are likely to be higher if the conservation area has attractive characteristics, as described above, which ultimately is driven by visitors preferences in a particular area. The Recreation Opportunity Spectrum (ROS) is a method that can be used to analyze the preferences visitors have for specific areas. The method divides visitors into three distinct groups: urbanists, neutralists and purists, where each is assumed to have different preferences for site attributes like tranquility, infrastructure, etc. Visitor surveys like these can provide valuable information for managers about visitors' preferences, which create a basis for better management of recreational areas. This can help attract more visitors by avoiding conflicts, improving infrastructure, etc.

However, the total visitor numbers are not necessarily enough to produce significant economic impact if visitors do not stay long. For example, Nuuksio National Park near Helsinki has significant number of visitors, but impacts on the local economy are relatively small as most visitors come from neighboring areas. The economic impact of Koli National Park was in 2015 about five times higher than that of Nuuksio National Park (when the park was the primary target), even if the number of visitors was only half of Nuuksio's and is located further from bigger cities (see also Koskeli-Ratamaa 2016)..$^{2}$

Availability of services is an important factor impacting on willingness to visit a conservation area, and thus on local economic impact. Services need not be directly related to conservation (like guiding services) but could rather be services that give reasons for visitors to stay longer in the area (like nearby skiing slopes, attractive hotels

$4^{2}$ www.metsa.fi/web/en/economicbenefitsofnationalparks 
or spas). In addition to availability of different kind of services that attract visitors to stay longer in the area, also infrastructure (paths, camping sites, visitor centers etc.) of the conservation area has impact on visitor numbers.

Biodiversity values do not necessarily coincide with visitor numbers and economic benefits. Areas which may be valuable from a biodiversity point of view, but which do not have national park status or which are located far from cities or major tourist centers, attract less visitors and are likely to create less economic impact.

\section{Can the design of conservation measures or policies help stimulate positive} economic impacts?

Some studies have suggested that policy can be designed in such a way to assist rather than hinder the expression of positive economic impacts from conservation.

One study found that protected areas in northern Sweden provide only a weak contribution to jobs and tourism, in part because many summer activities are free (camping, hiking) (Byström \& Müller, 2014). Winter activities however tend to generate more profits and jobs as more activities in or nearby natural and cultural heritage sites involve actual payments (for downhill skiing). The same study also suggested that current policies limiting commercial activities in Swedish National Parks may help promote biodiversity values, but at the cost of other economic benefits associated with job creation (Byström \& Muller, 2014). Furthermore, Lundmark (2005) suggested a "leakage problem" related to current tax policy, which makes it difficult for local communities to capture their portion of tax income as seasonal workers in the tourism industry are required to pay taxes in their home community, which prevents the flow of money to local sources.

Some studies from Sweden suggest that spending from tourism can stimulate local economies and labor markets (Fredman \& Yuan, 2011, Huhtala, 2007). However, there is a lack of evidence on job creation because of conservation, in particular whether or not growth of tourism-related jobs are the result of declining employment in other sectors (forestry) or whether the tourism sector is indeed enhanced by conservation. Furthermore, it is difficult to separate which impacts are actually because of conservation areas or other natural or cultural heritage and which part of income is related to other reasons of visits. This is also reflected in the relatively vague definition of "nature-based tourism" and the difficulties to separate economic figures related to that from national statistics. In Finnish Lapland, for example, where nature is the main attraction, tourism is one of the most important sectors of the region creating jobs and income. It is difficult, however, to separate what is the actual share of income created by the existence of conservation areas.

It is obvious that regional differences in economic impacts are likely to be high. Attractive natural and cultural heritage areas can generate direct job opportunities in the hotel and restaurant industries, other services and the transport sector as well as indirect and induced impacts. However, these effects are not studied in detail in the Nordic countries. These questions are however more deeply studied in e.g. the US (Thomas and Kontz 2015), Germany (Schmidt 2006) and the UK (Findlay et al. 2000), showing significant effects on income and labor markets. 
One way of generating income and jobs is through environmental offsetting aimed at protecting or restoring natural and cultural heritage following environmental damage from e.g., infrastructure development. A recent report from the UK suggests that compensation requirements have led to a number of jobs and income (Ben Dor et al., 2015, Duke \& Ten Kate, 2014) which is particularly relevant in the Nordic context given current discussion about increasing compensation requirements (Miljödepartementet 2016: 23, \& Miljødirektoratet In press).

Policy design can help address distributional impacts that arise from a conservation policy. For example, historical demographic patterns suggest that protecting or restoring natural and cultural heritage can impose a disproportionally high cost on local populations, while providing general benefits to the entire country (or globe). This can be seen e.g. in the establishment of forest conservation in Finland. Kniivilä et al. (2004) found that land conservation led to a net welfare loss for locals as costs (lost revenues, lost jobs) were higher than conservation benefits. Interestingly, however, the calculation was reversed for non-locals: the benefits of conservation exceed the costs. In such cases policy can help address conflicts through the use of economic compensation (e.g., transfer payments) that offset negative impacts to a particular group. For example, the increased income from nature-based tourism could be used to compensate for decreased income/employment to the forestry sector.

\section{Given that conservation costs money, how can financial flows help finance} such measures?

Conservation measures are not free, but individuals value conservation outcomes and are willing to pay for them. Thus, income generation on the local level can help land managers finance conservation. But a key question is: who should pay - users, non-users, or both?

In the USA visitors to national parks pay an entrance fee. Payment for access not only signals the value provided by nature but also provides financial resources to improve the quality of the resource. It also provides the opportunity for locallygenerated income to remain in local economies. In Nordic countries, resource management is generally paid by all taxpayers. As the Finnish and US examples above show, income created may well exceed the amount of taxpayers' money invested, regardless of who pays.

Both approaches have distributional impacts that are unavoidable:

- If all taxpayers contribute to a public good like a park, it ensures free access, but some argue it is unfair if people who never use the resource still have to pay for it. But this can be motivated by the fact that many non-users still value the existence of a resource even if they never use it.

- If users pay for access it may be more "fair" to non-users, but this too results in distributional impacts as it may restrict access for low-income users. 
Who wins and who loses from such scenarios depends on how individuals value the resource. For example, some individuals may reject the "pay for play" approach due to cultural reasons ("it's always been free") while others may accept this if the money is used to make valued improvements in their recreational experience.

Fees bring some amount of additional income to conservation sites. According to Thomas and Koontz, $10 \%$ of total income generated from national parks in the US were from "admission and fees"). They also provide the possibility for job opportunities in rural areas. However, the use of fees may affect social equality which, in turn, may require a shift in traditional Scandinavian attitudes about access to nature. Fundamentally, it is a question about whether free access is worth the cost to taxpayers, where the cost is the missed opportunity to capture income from resource users who have demonstrated a willingness to pay for access. The traditional Scandinavian approach does not capture this income (which may be large or small depending on the political decisions required to set the price of admission) and instead distributes the cost of conservation across all citizens - users and non-users.

Figure 11: What a view! From the Italian Road on Kullaberg, Sweden

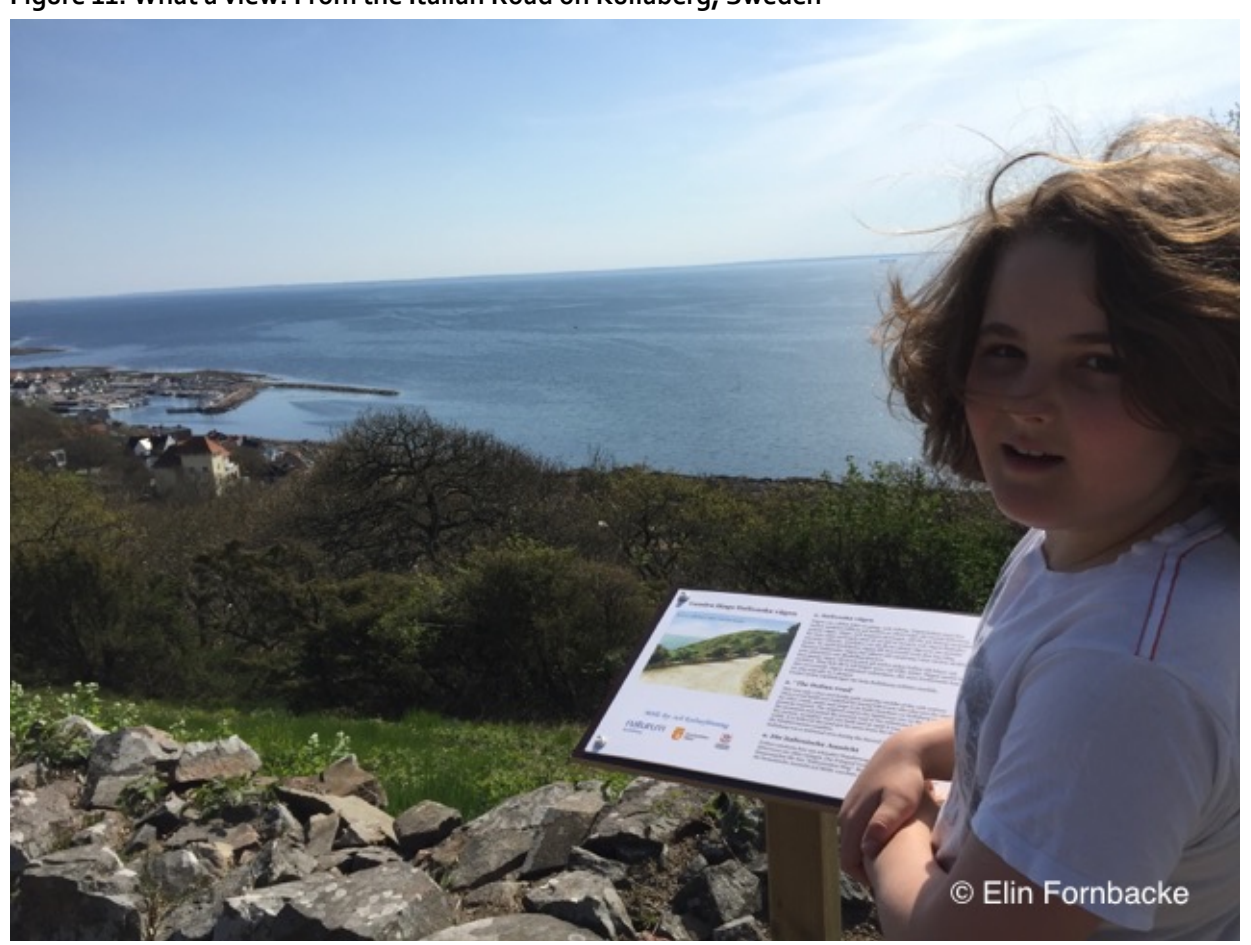





\section{Conclusions and policy recommendations}

This study has shown that protected natural and cultural areas in the Nordic countries provide a range of economic benefits to society. The starting point for evaluating welfare benefits should be the total economic value framework (TEV), which identifies the universe of benefits to society that may arise from protecting these resources. The benefits of conservation include both market and non-market benefits, where some are related to non-use values and others to use values. In the case of conservation, nonmarket benefits often play a significant role, which requires competence in environmental economic assessment. While transferring values from other contexts (so-called benefits transfer) is useful, it should be done with care.

The fact that different types of conservation measures can, in a best case scenario, lead to market and non-market benefits does not in and of itself argue for protection. Instead, these values should be compared to the opportunity costs of conservation, less tight restrictions etc. Addressing this question requires that decision-makers understand and assess the inevitable trade-offs that arise between competing goals. The most common trade-offs are between values associated with conservation on the one hand and development on the other, or between recreational user groups (e.g. noisy, vs. quiet recreation) or between competing biodiversity goals (e.g. habitat $X$ versus habitat $Y$ ). The choices made by decision makers and land managers can largely affect both the type and magnitude of value generated. Trade-offs are also present when addressing welfare impacts at different levels of the economy. Benefits may accrue to one group but costs to another. The suggested framework for addressing the trade-offs associated with alternative land use decisions is cost-benefit analyses.

In addition to non-market benefits, the specific regulations for a protected natural and cultural heritage site can also lead to economic impacts on a local level. Jobs and income can be created or lost. These economic impacts, which provide a complementary rather than substitute measure of economic benefit, provide decision-makers with information on how recreational users stimulate local economies (at tour companies, hotels, restaurants, retail trade, etc.) and how this can lead to income and job creation. These impacts are measured on three levels: direct, indirect and induced, and are most evident at local level whereas non-market benefits can be experienced further away, even at global scale.

A strict approach to conservation that focuses on biodiversity preservation and limits human use may restrict the potential for positive local economic impacts, but the link is not straightforward. In theory, reducing the number of visitors reduces the potential for positive impacts like jobs and income creation, although there may still be welfare benefits from conservation. In addition to conservation area characteristics like 
location, scenery and infrastructure, the structure of the local economy and leakages to other areas may affect the realization of economic impacts e.g. can the local area supply the needed services? Are inputs from other regions required (e.g., services, materials, labour)? Do employees live in the area or elsewhere?

\subsection{Key recommendations}

Policy makers need defensible economic approaches for measuring values, assessing trade-offs and evaluating policy implication. These tools should help assess, for example, the benefit of protecting nature on the one hand with the benefits provided by human development/recreational use on the other. We suggest the focus on economics should lie in two areas:

(1) Measure and capture the welfare benefits of different kinds of conservation. Nonmarket valuation is challenging and resource-intensive, but provides valuable information to decision-makers to help direct scarce public resources to issues that matter most to citizens. This information can contribute - and in fact improve upon procedures that are already in use by managers today, in particular public comment periods for conservation proposals. For example, information about the value of resources (and uncertainty surrounding these estimates) can provide key input to the debate about what areas to manage, how much to protect, how to protect, etc. This is particularly relevant in the current shift toward multiple use management, which requires that policy makers can meet the needs of diverse users. Contributions from NCM should include the following:

- Support and finance compilations of key information from Nordic valuation studies, which provides key input into welfare analysis. An update of the previously by NCM financed database Nordic Environmental Database (NEVD) (Navrud et al., 2007), would help to reduce the search costs for local managers to identify the potential values at stake associated with natural and cultural heritage.

Furthermore, such a database would facilitate efficient CBA based on benefits transfer and also ease the countries' work with valuing ecosystem services.

- Distribute knowledge on best practice for benefits transfer within and between the Nordic countries. Benefits transfer is a method that takes values from previous studies and transfers them to a local policy site to estimate economic values at stake from certain projects. It is a cost effective way of lifting welfare values. However, a prerequisite for benefit transfer is that the user understands limitations related to the method and restrictions related to valuation studies. Several studies have investigated theoretical and methodological challenges from using benefits transfer. However, key information needs for the Nordic context include empirical evidence on the validity of such transfer as well as recommendation on how best to transfer between Nordic countries or across heterogeneous areas (e.g., rural vs. urban, etc.). 
- For key Nordic protected a reas or habitats, consider financing a primary valuation study. Key habitats like national parks that are found across many Nordic countries could be ripe for a large-scale valuation study that is partially or fully funded by NCM. This type of empirical study could provide inspiration and guidance for conservation in Nordic countries.

- Identify and highlight successful use of environmental CBA in the Nordic context. Although well supported in the literature, the use of environmental CBA to support decision-making is still limited. NCM could help by highlighting environmental issues where this could be helpful. Note that CBA can be carried out on a range of scales depending on the resources available for assessment. More effective use of CBA in the future will require, among other things, improvement in valuation studies and benefits transfer as discussed above.

(2) Improve the measurement of economic impacts that can arise locally from conservation. In addition to welfare values that different types of conservation can generate, local actors are often interested in the potential for other positive economic impacts like job and income creation. Nordic countries need to be better at assessing these types of impacts. While frequently used in the US and elsewhere, these types of analyses are only used sporadically in Nordic countries, with Finland standing out as an exception. Contributions from NCM should include the following:

- Highlight Finnish examples. The benefits of an economic impact study could be highlighted via Finnish case studies. This would demonstrate not only the importance of this information for decision makers but may also inspire other countries to conduct these analyses in a more regular and systematic way, as is done in Finland.

- Facilitate distribution of key input data. An economic impact analyses requires economic models that rely on data inputs such as number of visitors to a site, where they come from, how much they spend, and other travel and recreational use patterns. Without this information, these analyses cannot be carried out. While such information must be collected on a local level, NCM can nonetheless play an important roll by highlighting successful examples in Finland and abroad, distributing and sharing methods and data collection among Nordic countries, and/or developing short "on line" case studies that demonstrate the usefulness of such analyses and the need for data input to support them. This work can build upon a previous project financed by NCM TEG (Kajala et al., 2007).

- Consider ways to improve financing management of protected natural and cultural heritage areas. A key result from Chapter 4 on welfare values is that people are willing to pay to protect and/or experience these areas. This has important implications for financing conservation with limited public funds. This willingness to pay by users represents a potential source of revenue. The collection of such revenue - and the future use of it - would require a political discussion about special conservation funds or even admission fees for Nordic conservation areas. 
To inform such a discussion and to provide key lessons learned NCM could support pilot studies at a conservation site. Preferably this site would have established infrastructure and high demand by users (popular mountain bike, cross country ski tracks or well known previously historic sites). 


\section{References}

Aanesen, M., Armstrong, C., Czajkowski, M., Falk-Petersen, J., Hanley, N. and Navrud, S. (2015). Willingness to pay for unfamiliar public goods: Preserving cold-water coral in Norway. Ecological Economics 112: 53-67. https://doi.org/10.1016/j.ecolecon.2015.02.007

Anon (1992) Agenda 21. In: United Nations Sustainable Development, United Nations Conference on Environment \& Development. 1992 United Nations. p. 343.

Atkinson, Giles, and Susana Mourato. (2008). "Environmental Cost-Benefit Analysis." Annual Review of Environment and Resources 33 (1): 317-44. https://doi.org/10.1146/annurev.environ.33.020107.112927

Arcadis, Eftec \& ECNC. (2011). Recognizing Natura 2000 benefits and demonstrating the ecnomic benefits of conservation measures. European Commission Project number 11639. Version 2.

Artell, J. (2013). Lots of value? A spatial hedonic approach to water quality valuation. Journal of Environmental Planning and Management. In presssamo tourism area, Finland. For. Policy Econ. 47: 4-13.

Balmford, A., Rodrigues, A., Walpole, M., ten Brink, P., Kettunen, M., Braat, L., de Groot, R. (2008). The Economics of Ecosystems and Biodiversity: Scoping the Science. European Commission. Cambridge, UK.

Bartkowski, B., Lienhoop, N., Hansjürgens, B. (2015). Capturing the complexity of biodiversity: A critical review of economic valuation studies of biological diversity. Ecological Economics 113, 1-14.

Barton, D., Lindhjem, H., Magnusson, K., Holen, S. (2012). Valuation of Ecosystem Services from Nordic Watersheds. From awareness raising to policy support? (VALUESHED). TemaNord 2012. 506. Nordic Council of Ministers. Copenhagen.

BenDor T, Lester TW, Livengood A, Davis A, Yonavjak L (2015). Estimating the Size and Impact of the Ecological Restoration Economy. PLOS ONE 10(6).

https://doi.org/10.1371/journal.pone.0128339

Bowitz, E. and Ibenholt, K. (2009). Economic impacts of cultural heritage - Research and perspectives. Journal of Cultural Heritage 10: 1-8. https://doi.org/10.1016/j.culher.2008.09.002

Boyd J \& Banzhaf S (2007). What are ecosystem services? The need for standardized environmental accounting units. Ecological Economics 63: 616-626.

https://doi.org/10.1016/j.ecolecon.2007.01.002

Bredahl Jacobsen, J. Hedemark Lundhede, T. Martinsen, L. Hasler, B. Jellesmark Thorsen, B. (2011). Embedding effects in choice experiment valuation of environmental preservation projects. Ecological Economics 70. 1170-1177. https://doi.org/10.1016/j.ecolecon.2011.01.013

Broberg, T. (2007). Assessing the non-timber value of old growth forests in Sweden. Umeå Economic Studies No. 712. https://doi.org/10.1016/j.jenvman.2007.05.016

Broberg, T. \& Brännlund, R. On the value of large predators in Sweden: A regional stratified contingent valuation analysis. Journal of Environmental Management 88. 1066-1077.

Bowitz, E. and Ibenholt, K. (2009). Economic impacts of cultural heritage - Research and perspectives. Journal of Cultural Heritage 10: 1-8. https://doi.org/10.1016/j.culher.2008.09.002 Bue Bjørner, T. Termansen, M. (2014). Brugsværdien af naturområder i Danmark. Nationaløkonomisk tidskrift 2014:1.

Busse Nielsen, A. Bøye Olsen, S. Lundhede, T. (2007). An economic valuation of the recreational benefits associated with nature- based management practices. Landscape and Urban Planning 80. 63-71. https://doi.org/10.1016/j.landurbplan.2006.06.003

Byström, J. Müller D. K. (2014). Tourism labor impacts of national parks. Zeitschrift für Wirtschaftsgeographie. Jg. 58. Heft 2-3, S. 115-126. 
de Groot, R. S., Wilson, M., Boumans, R. (2002). A typology for the description, classification and valuation of ecosystem functions, goods and services. Ecological Economics 41: 393-408. https://doi.org/10.1016/Sog21-8009(02)00089-7

de Groot, R. (2006). Function-analysis and valuation as a tool to assess land use conflicts in planning for sustainable, multi-functional landscapes. Landscape and Urban Planning 75, 175-186. https://doi.org/10.1016/j.landurbplan.2005.02.016

Duke, G and ten Kate, K.(2014). Exploring lessons learned from biodiversity offsetting markets in other countries that could inform appraisal of options for delivering offsets in England. Final report to Defra (project code WC1098). Forest Trends, Washington D.C.

Findlay, A., Short, D., Stockdale, A. (2000). The repopulation of rural Scotland. Opportunity and threat. In: Journal of Rural Studies, (16)2, 243-257.

Fischer, B., I. Bateman, and R.K. Turner. (2011). Valuing Ecosystem Services: Benefits, Values, Space and Time. Working Paper Series No. 3, Ecosystem Services Economics, UN Env Prog, Nairobi. http://www.bioeconnetwork.org/pages/UNEP_publications/03\%20Valuing\%2oEcosystem\%2oServices.pdf

Fredman P; Boman M; Lundmark L; Mattsson, L (2008). Friluftslivets ekonomiska värden- en översikt. Friluftsliv i förändring. Rapport nr 5 .

Fredman, P. \& Emmeling, L. (2001). Wilderness purism, willingness to pay and management preferences: a study of Swedish mountain tourists. Tourism Economics 7 (1) 5-20. https://doi.org/10.5367/000000001101297702

Fredman, P. \& Yuan, M. (2011). Primary Economic Impacts at Three Spatial Levels: The Case of Fulufjället National Park, Sweden. Scandinavian Journal of Hospitality and Tourism, 74-86. https://doi.org/10.1080/15022250.2011.629910

Freeman, M. A. Herriges, J.A. \& Kling, C.L. (2014). The Measurement of Environmental and Resource Values - Theory and Method. Third edition. Resources for the future press. Washington DC.

Grammatikopoulou,I., Pouta, E., Salmiovirta, M. \& Soini, K. (2012). Heterogeneous preferences for agricultural landscape improvements in southern Finland. Landscape and Urban Planning, 107: 181-191. https://doi.org/10.1016/j.landurbplan.2012.06.001

Haefele, M.,Loomis, J., Bilmes, L J. (2016). Total Economic Valuation of the National Park Service Lands and Programs: Results of a Survey of the American Public. HKS Faculty Research Working Paper Series.

Haltia, E. (2015). Contingent valuation and choice experiment of citizens' willingness to pay for forest conservation in southern Finland. Doctoral dissertation. University of Helsinki, Faculty of Agriculture and Forestry, Department of Forest Sciences.

Hasund, K-P, Kataria, M. \& Lagerkvist, C.J. (2011). Valuing public goods of the agricultural landscape: a choice experiment using reference points to capture observable heterogeneity. Journal of Environmental Planning and Management, 54:1, 31-53. https://doi.org/10.1080/09640568.2010.502753

Headwaters Economics. (2013). Summary Report: The Economic Costs and Benefits of a New National Park and Recreation Area for Penobscot and Piscataquis Counties, Maine.

Hougner, C. Colding, J. Söderqvist, T. (2006). Economic valuation of a seed dispersal service in the Stockholm National Urban Park, Sweden. Ecological Economics 59 364-374.

https://doi.org/10.1016/j.ecolecon.2005.11.007

Huhtala M. (2007). Assessment of the local economic impacts of national park tourism. The case of Pallas - Ounastunturi National Park. In: Forest Snow and Landscape Research, (81)1, 223-238.

Huhtala, A. \& Lankia, T. (2012). Valuation of trips to second homes: do environmental attributes matter? Journal of Environmental Planning and Management 55, 6, 733-752. https://doi.org/10.1080/og640568.2011.626523

Jobsvogt, N. Hanley, N. Hynes, S, Kenter, J, Witte, U. (2014). Twenty thousand sterling under the sea: Estimating the value of protecting deep-sea biodiversity. Ecological Economics 97. 1019. https://doi.org/10.1016/j.ecolecon.2013.10.019 
Jones, C., Newsome, S., Macbeth, J. (2016). Understanding the conflicting values associated with motorized recreation in protected areas. Ambio 2016, 45. 323-330.

https://doi.org/10.1007/s13280-015-0721-1

Juutinen, A., Kosenius, A.-K, Ovaskainen, V. (2014). Estimating the benefits of recreationoriented management in state-owned commercial forests in Finland: a choice experiment. Journal of Forest Economics 20: 396-412. https://doi.org/10.1016/j.jfe.2014.10.003

Juutinen, A., Mitani, Y., Mäntymaa, E., Shoji, Y., Siikamäki, P. \& Svento, R. (2011). Combining ecological and recreational aspects in national park management: a choice experiment application. Ecological Economics 70: 1231-1239. https://doi.org/10.1016/j.ecolecon.2011.02.006

Kajala, L., Almik, A., Dahl, R., Dikšaitè, L., Erkkonen, J., Fredman, P., Jensen, F. Søndergaard, Karoles, K., Sievänen, T., Skov-Petersen, H., Vistad, O. I. och Wallsten, P. (2007).

Besökarundersökningar i naturområden - en vägledning baserad på erfarenheter från de nordiska och baltiska länderna.

Kettunen, M., Vihervaara, P., Kinnunen, S., D'Amato, D., Badura, T., Argimon, M. and Ten Brink, P. (2012). Socio-economic importance of ecosystem services in the Nordic Countries. Synthesis in the context of The Economics of Ecosystems and Biodiversity (TEEB). ISBN 978-92893-2446-5.

Kniivilä, M. (2004). Contingent valuation and cost-benefit analysis of nature conservation: a case study in North Karelia, Finland. D.Sc. (Agr. and For.) thesis. University of Joensuu, Faculty of Forestry. 69 pages +4 articles.

Kniivilä, M. (2006). Users and non-users of conservation areas: Are there difference in WTP, motives and validity of responses in CVM surveys? Ecological Economics 59: 530-539. https://doi.org/10.1016/j.ecolecon.2005.11.017

Kniivilä, M., Ovaskainen, V. and Saastamoinen, O. (2002). Costs and benefits of forest conservation: regional and local comparisons in Eastern Finland. Journal of Forest Economics 8(2): 131-150. https://doi.org/10.1078/1104-6899-00008

Kniivilä, M. and Saastamoinen, O. (2002). The opportunity costs of forest conservation in a local economy. Silva Fennica 36(4): 853-865. https://doi.org/10.14214/sf.526

Koskeli-Ratamaa, A. (2016). Kolin kansallispuiston kävijätutkimus 2014. Metsähallituksen luonnonsuojelujulkaisuja. Sarja B 216, Metsähallitus, 71 p.

Lehtoranta, V., Sarvilinna, A., and Hjerppe, T. (2012). Purojen merkitys helsinkiläisille Helsingin pienvesiohjelman yhteiskunnallinen kannattavuus. The significance of streams for the residents of the City of Helsinki Contingent Valuation Study for the feasibility of the Small Water Action Plan. Finnish Environment Institute SYKE. Finnish Environment 5. 66 p. ISBN 978-952-113984-0 (PDF). In Finnish.

Liienhoop, N. MacMillan, D. (2007). Valuing wilderness in Iceland. Estimation of WTA and WTP using the market stall approach to contingent valuation. Land Use Policy 289-295.

https://doi.org/10.1016/j.landusepol.2005.07.001

Lindhjem, H. and Mitani, Y. (2012). Forest owners' willingness to accept compensation for voluntary conservation: A contingent valuation approach. Journal of Forest Economics 18 (4): 290-302. https://doi.org/10.1016/j.jfe.2012.06.004

Lindhjem, H., Grimsrud, K., Navrud, S. and Kolle, S.O. (2015). The social benefits and costs of preserving forest biodiversity and ecosystem services. Journal of Environmental Economics and Policy 4(2): 202-222. https://doi.org/10.1080/21606544.2014.982201

Lundmark, L. (2005). Economic restructuring into tourism in the Swedish mountain range. In: Scandinavian Journal of Hospitality and Tourism, (5)1, 23-45.

https://doi.org/10.1080/15022250510014273

Lundmark, L J., Fredman, P., Sandell, K. (2010). National parks and protected areas and the role for employment in tourism and forest sectors: a Swedish case. Ecology \& society, 15(1): 19. https://doi.org/10.5751/ES-03175-150119

MA (2005). Millenium Ecosystem Assessment - Ecosystems and Human Wellbeing: synthesis. Island Press, Washington DC. 
Metsähallitus Parks \& Wildlife Finland (2016).

http://www.metsa.fi/documents/10739/1366250/Localeconomyimpacts_2015_Finnish_Nation al_Parks.pdf/6cf1e10e-6aza-4d81-95b7-06e83977d38a

Miljödepartementer, Direktiv (2016).23. Utredningen om en effektivare och mer konsekvent tillämpning av ekologisk kompensation.

Miljødirektoratet, In presss. Veileder for økologisk kompensasjon.

Mitchell, R., Carson, R. (1989). Using surveys to value public goods: The contingent valuation method, Resources for the Future, Washington D.C.

Naturvårdsverket (2015). Organiserat friluftsliv och naturturism I skyddad natur. Vägledning för förvaltare. Rapport 6686.

Nikodinoska, N. Paletto, A. Franzese, P, P. Jonasson, C. (2015). Valuation of Ecosystem Services in Protected Areas: The Case of the Abisko National Park (Sweden). Journal of Environmental Accounting and Management 3(4) 355-369. https://doi.org/10.5890/JEAM.2015.11.005

OECD (2014). OECD Environmental Performance Reviews: Iceland 2014, OECD Publishing.

Olaussen, J.O. and Liu, Y. (2011). On the willingness-to-pay for recreational fishing-escaped farmed versus wild Atlantic salmon. Aquaculture Economics \& Management 15 (4):245-261. https://doi.org/10.1080/13657305.2011.624573

Ovaskainen, V., Neuvonen, M. and Pouta, E. (2012). Modelling recreation demand with respondent-reported driving cost and stated cost of travel time: a Finnish case. J. For. Econ. 18: 303-317. Pascual. https://doi.org/10.1016/j.jfe.2012.06.001

Pascual, U., Termansen, M., Hedlund, K., Brussard, L., Faber, J.h., Foudi, S., Lemanceau., Liv Jørgensen, S. (2015). On the value of soil biodiversity and ecosystem services. Ecosystem Services 15. 11-18. https://doi.org/10.1016/j.ecoser.2015.06.002

Pearce, D.W. \& Turner, R.K. (1990). Economics of natural resources and the environment. Harvester Wheatsheaf, London.

Powers, M. (2001). The Economic Impact of the Proposed Maine Woods National Park \& Preserve. Forest Ecology Network. Volume 5, No.2.

Reyes, J., \& Mates, W. (2004). The Economic Values of New Jersey State Parks and Forests. New Jersey Department of Environmental Protection. Division of Science, Research \& Tehnology.

Saelen, H. and Ericson, T. (2013). The recreational value of different winter conditions in Oslo forests: A choice experiment. Journal of Environmental Management 131: 426-434. https://doi.org/10.1016/j.jenvman.2013.10.006

Saunders, J., Tinch, R., and Hull, S. (2010). Valuing the Marine Estate and UK Seas: An Ecosystem Services Framework. The Crown Estate, 54 pages, March 2010. ISBN: 978-1-906410-15-5.

Schmidt J. (2006). Regionalökonomische Wirkungen von Großschutzgebieten. Eine empirische Studie zu den Nationalparken in Deutschland. Hamburg.

Schägner, J. P. Brander, L. Maes, J, Paracchini, M L. Hartje, V. (2016). Mapping recreational visits and values of European national Park by combining statistical modelling and unit value transfer. Journal for Nature Conservation 31. 71-84. https://doi.org/10.1016/j.jnc. 2016.03.001

TEEB (2010). The economics of ecosystems and biodiversity - mainstreaming the economics of nature: a synthesis of the approach. Conclusions and Recommendations of TEEB.

Thomas, C C., \& Koontz, L. (2015). 2015 National Park Visitor Spending Effects- Economic Contributions to Local Communities, States and the Nation. Natural Resource Report.

Tyrväinen, L., Mäntymaa, E. and Ovaskainen, V. (2014). Demand for enhanced forest amenities in private lands: the case of the Ruka-Kuusamo tourism area, Finland. For. Policy Econ. 47:4-13. https://doi.org/10.1016/j.forpol.2013.05.007

UK NEA (2011). The UK National Ecosystem Assessment: Synthesis of the Key Findings. UNEPWCMC, Cambridge.

United Nations, (1987) Our Common Future - Brundtland Report. Oxford University Press, p. 204.

Unsworth, R. E., \& Paterson, R. W. (1999). Economic assessment of the proposed Aldo Leopold National Wildlife Refuge. Report prepared for the U.S. Fish and Wildlife Service. 
Vatanen, E \& Kajala, L. (2015). Kansallispuistojen, retkeilyalueiden ja muiden lvontomatkailullisesti arvokkaiden suojelualueiden paikallistaloudellisten vaikutusten arviointimenetelmän kertoimien päivitys 2014 (Update of multipliers used by the method assessing the local economic impacts of national parks, hiking areas and other protected areas valuable as nature tourism destinations, 2014). Metsähallituksen luonnonsuojelujulkaisuja. Sarja A 213, 28 p.

Vatanen, E., Ovaskainen, V. \& Hyppönen, M. (2014). Luontomatkailu alue-ja paikallistaloudessa. In: Tyrväinen, L., Kurttila, M. \& Sievänen, T. (eds.). Hyvinvointia metsästä. Suomalaisen Kirjallisuuden Seura. Pp. 153-162.

Vesterinen, J., Pouta, E., Huhtala, A., Neuvonen, M. (2010). Impacts of changes in water quality on recreation behavior and benefits in Finland. Journal of Environmental Management 91: 984-994. https://doi.org/10.1016/j.jenvman.2009.12.005

von Boehm, A. and Kajala, L. (2015). Raaseporin, Kuusiston ja Kajaanin rauniolinnojen, Svartholman merilinnoituksen ja Langinkosken luonnonsuojelvalueen kävijätutkimus 2014. Metsähallituksen luonnonsuojelujulkaisuja. Sarja B 213, Metsähallitus, 223 s.

Zhang, J., Madsen, B. and Jensen-Butler, C. (2007). Regional economic impacts of tourism: the case of Denmark. Regional Studies 41:6: 839-854. https://doi.org/10.1080/00343400701281733 



\section{Svensk sammanfattning}

Natur- och kulturarven är viktiga resurser som levererar ekonomiska värden för medborgarna i de nordiska länderna. Denna rapport illustrerar de ekonomiska värden dessa skapar och diskuterar viktiga och oundvikliga avvägningar mellan olika värden som möter beslutsfattare ansvariga för förvaltningen av dessa resurser.

Denna rapport har tre mål: att översiktligt beskriva existerande skydd av natur- och kulturarven i de nordiska länderna, att illustrera både vilken typ och storlek av värden detta kan medföra, samt att diskutera hur valet av skyddsform medför avvägningar mellan värden som påverkar välfärd, och vilka policyimplikationer detta medför. Ett delmål är att belysa hur miljöekonomi kan bidra med insikter för att skapa bättre beslut och även bistå med konkreta policyrekommendationer. Studien fokuserade på de nordiska länderna, främst Danmark, Finland och Sverige, men berör även Island och Norge. Analysen baserades på existerande forskning och litteratur.

Analysen utgick ifrån att undersöka de välfärdseffekter (dvs. påverkan på välmående) som skapas av natur- och kulturarven, genom att utgå från ramverket "Totalt ekonomiskt värde" (TEV). Ramverket identifierar en mångfald av potentiella ekonomiska värden som natur- och kulturarv kan skapa för samhället. Nyttorna som identifieras genom TEV inkluderar direkta användarvärden, såsom rekreationsupplevelser och indirekta användarvärden såsom ökad resiliens. Vidare identifieras också nyttor som klassas som icke-användarvärden, dvs. de värden individer har för en tjänst eller plats trots att de aldrig besöker eller nyttjar den.

Ett antal värderingsstudier analyserades, och dessa visade att det finns konkreta ekonomiska värden som skapas av de tjänster natur- och kulturarven tillhandahåller. Vanliga medborgare, personer som nyttjar områden för rekreation och turister upplever ökad välfärd av att natur- och kulturarvens tjänster skyddas och uppvisar betalningsvilja för åtgärder som ökar kvantiteten och/eller kvaliteten av dessa tjänster och upplevelser.

Vidare visar de regionalekonomiska studier som analyserades att marknadsbaserade nyttor skapas. Exempel på detta är jobbskapande och inkomster för företag. De viktigaste aspekterna som påverkar storleken på de ekonomiska effekterna från en specifik plats är antalet besökare, men även andra faktorer som exempelvis nivån av regleringar, platsens läge, vilka tjänster som erbjuds, vilka miljäattribut som finns, eventuella kostnader för tillträde, platsens beteckning (National park, Världsarv, etc), och tillgången till kompletterande platser och attraktioner i närheten, påverkar storleken på de värden som skapas. Den lokala ekonomins struktur och eventuella "läckage" till andra områden (att t.ex. skatteintäkter inte stannar inte) påverkar också vilka ekonomiska effekter natur- och kulturarven har på regional skala.

Att olika typer av skydd av natur- och kulturarv skapar marknads- och ickemarknadsnyttor innebär inte per automatik att en specifik typ av skydd eller åtgärd bör genomföras. Denna rapport visar att de nyttor som skapas måste jämföras med 
alternativkostnaden för åtgärderna för att bedöma om en åtgärd är samhällsekonomiskt lönsam eller ej. För detta krävs att nyckelavvägningar mellan olika typer av värden identifieras, t.ex. om vissa värden skapas på bekostnad av andra.

Den vanligast förekommande avvägningarna är de mellan skydd av ett område mot tillåtelse för exploatering (t.ex. skogsbruk, eller byggnationer), avvägningar mellan olika typer av rekreationsaktiviteter (t.ex. quiet vs. noisy), samt mellan olika mål för biologisk mångfald. Kostnads-nyttoanalys är den metod som föreslås för att adressera och utvärdera avvägningar kring olika markanvändningsbeslut.

De huvudsakliga rekommendationerna från denna studie är: (1) Mät och bedöm välfärdseffekter. Målet med åtgärder som syftar till att skydda natur- och kulturarv bör baseras på att maximera välfärd, och detta kräver att välfärdseffekter bedöms, företrädesvis i monetära termer, (2) Mät och bedöm regionalekonomiska effekter. Ett komplement till att bedöma välfärdseffekter är att mäta de regionalekonomiska effekter som skapas till följd av skyddade natur- och kulturarv. Sådana studier bör fokusera på att använda tillgängliga nationalekonomiska metoder för att bedöma hur specifika åtgärder kan påverka inkomster, skatteintäkter och jobbskapande. 


\section{Soumen yhteenveto}

Luonto ja kulttuuriperintökohteet tuottavat pohjoismaalaisille monenlaisia hyötyjä. Tämä raportti esittelee luonnon- ja kulttuuriperintöön liittyviä taloudellisia arvoja sekä tarkastelee kohteiden käyttöön liittyviä keskeisiä vaihtosuhteita, joita päätöksentekijät joutuvat alueiden kohdalla arvioimaan.

Raportilla on kolme tavoitetta. Ensinnäkin kuvaillaan lyhyesti pohjoismaisia tapoja toteuttaa suojelua. Toiseksi havainnollistetaan esimerkkien avulla suojelun luomaa taloudellista arvoa. Kolmanneksi arvioidaan suojelutoimenpiteisiin liittyviä keskeisiä vaihtosuhteita sekä politiikkavaikutuksia. Raportissa pyritään nostamaan esiin taloudellisia näkökulmia, joita voidaan käyttää päätöksenteon tukena. Tutkimuksessa keskitytään Pohjoismaihin ja näistä erityisesti Tanskaan, Suomeen ja Ruotsiin. Myös Islanti ja Norja ovat tarkastelussa mukana. Tutkimus perustuu olemassa olevaan taloustieteelliseen kirjallisuuteen.

Tarkastelun lähtökohtana on luonnon- ja kulttuuriperinnön tuottamien hyvinvointivaikutusten arvioiminen kokonaisarvon (total economic value, TEV) käsitettä hyödyntäen. Kokonaisarvokehikkoa käyttäen voidaan määritellä suojelualueista yhteiskunnalle potentiaalisesti syntyvät erilaiset taloudelliset hyödyt. Hyötyjä ovat muun muassa suorat käyttöarvot kuten virkistysarvot sekä epäsuorat käyttöarvot. Lisäksi alueilla voi olla optioarvoa (esim. mahdollisuus käyttää niitä myöhemmin) ja ne voivat tuottaa ei-käyttöarvoja myös henkilöille, jotka eivät koskaan vieraile alueilla.

Raportissa tarkastellut arvottamistutkimukset osoittavat, että luonnon- ja kulttuuriperintökohteilla on taloudellista arvoa. Kohteiden suojelu lisää tavallisten kansalaisten, virkistyskäyttäjien ja/tai turistien hyvinvointia. Tutkimusten mukaan ihmiset ovat myös halukkaita maksamaan toimenpiteistä, jotka lisäävät näiden kokemusten määrää tai laatua.

Arvottamistutkimusten lisäksi taloudellista hyötyä voidaan arvioida aluetaloudellisten vaikutusten analyyseillä, joilla voidaan arvioida esimerkiksi työllisyysja tulovaikutuksia. Saadun aluetaloudellisen hyödyn määrään vaikuttaa keskeisesti kävijöiden määrä, mutta myös muut tekijät kuten alueen käyttörajoitukset, sijainti, palvelutarjonta, alueen luonnonympäristöön liittyvät ominaispiirteet, vierailun kustannukset, alueen status sekä vaihtoehtoisten alueiden olemassaolo ja niiden läheisyys vaikuttavat siihen tuottaako alue taloudellista hyötyä. Lisäksi alue- ja paikallistalouden rakenne ja vuodot muille alueille ( $\mathrm{mm}$. muvalle maksetut verot) vaikuttavat paikallis- ja aluetaloudellisen hyödyn määrään.

Se, että suojelu tuottaa taloudellisia hyötyjä, joko markkinahyötyjä tai markkinattomia, ei taloudellisesta näkökulmasta katsottuna yksinään riitä perusteluksi tietyntasoiselle suojelulle. Hyvinvoinnin lisäämisen edellytyksenä on, että suojelun hyötyjä arvioidaan myös suhteessa sen vaihtoehtoiskustannuksiin. Tähän tarvitaan 
keskeisten vaihtoehtojen vaikutusten vertailua. Vaihtoehtoinen käyttömuoto suojelulle voi olla muu taloudellinen käyttö (esim. käyttö metsätaloudessa tai rakentamisessa) ja tällöin suojelun taloudellisia vaikutuksia on verrattava näiden käyttömuotojen vaikutuksiin. Oleellista voi olla myös verrata kilpailevien virkistyskäyttömuotojen vaikutuksia (esim. hiljaisuutta vaativat aktiviteetit vs. muut) tai keskenään ristiriidassa olevien monimuotoisuustavoitteiden toteuttamisen vaikutuksia. Eri maankäyttömuotoihin liittyviä vaikutuksia voidaan arvioida kustannushyötyanalyysin kehikossa.

Tämän tutkimuksen keskeiset suositukset ovat seuraavat: 1) Identifioi ja mittaa hyvinvointivaikutukset. Toimenpiteet, joilla tavoitellaan luonnonperinnön ja kulttuuriperinnön suojelua pitää perustua hyvinvointivaikutusten maksimointiin. Tämän arvioimiseen tarvitaan taloudellisten hyötyjen mittaamista, mieluiten rahamääräisenä. 2) Identifioi ja mittaa aluetaloudelliset vaikutukset. Hyvinvointivaikutusten arviointia täydentää paikallisten markkinahyötyjen arviointi. Olemassa olevia taloustieteellisiä menetelmiä toimenpiteiden alue- ja paikallistaloudellisten vaikutusten arvioimiseen (mm. tulo- ja työllisyysvaikutukset sekä vaikutukset verotuloihin) olisi syytä käyttää nykyistä enemmän. 


\section{Appendix}

\section{Appendix 1: Studies that illustrate economic values from landscape scenery, cultural heritage and promoting recreational opportunities}

Table 1: Studies that illustrate economic values from landscape scenery, cultural heritage and promoting recreational opportunities

\begin{tabular}{|c|c|c|}
\hline Author, year and country & Description & Valuation result \\
\hline $\begin{array}{l}\text { Vesterinen et al. } 2010 . \\
\text { Finland. }\end{array}$ & $\begin{array}{l}\text { Estimates benefits of water quality improvements. } \\
\text { Focuses on use value. }\end{array}$ & $\begin{array}{l}\text { A water policy scenario with a 1-m improvement in water clarity for both inland and coastal waters } \\
\text { indicates that the consumer surplus would increase } 6 \% \text { for swimmers and } 15 \% \text { for fishers. Increased } \\
\text { water clarity would increase the frequency of close-to-home swimming and fishing, but had no } \\
\text { effect on boating. Net benefits of water clarity improvements are positive. } \\
\text { Method: Travel Cost Method. }\end{array}$ \\
\hline $\begin{array}{l}\text { Lehtoranta et al. } 2012 . \\
\text { Helsinki, Finland. }\end{array}$ & $\begin{array}{l}\text { Estimates the significance of streams for the } \\
\text { residents of Helsinki. The study measures the value } \\
\text { of improvement in the ecological status of streams, } \\
\text { resulting from dedicated restoration activity. Use } \\
\text { and non-use values. }\end{array}$ & $\begin{array}{l}\text { The streams and their surroundings supply a range of ecosystem services, e.g. prevention of erosion, } \\
\text { flood and storm protection, aesthetic value and maintenance of biological diversity and wilderness } \\
\text { values. The total benefit estimate was approximately EUR } 1.4 \text { million (2010) per year and about EUR 7.2 } \\
\text { million (2010) for the five year period of the fictional and regional Small Water Fund. The estimated } \\
\text { total value exceeded the total costs targeted to restoration many times. } \\
\text { Method: Contingent Valuation. }\end{array}$ \\
\hline $\begin{array}{l}\text { Artell, } 2013 . \\
\text { Finland. }\end{array}$ & $\begin{array}{l}\text { The study elicits the value of improved water } \\
\text { quality capitalised in Finnish recreational property } \\
\text { prices adjacent to the Baltic Sea, lakes and rivers. } \\
\text { Captures use values. }\end{array}$ & $\begin{array}{l}\text { The study finds that water usability has a positive effect on property prices. Waterfront properties } \\
\text { close to waters with "poor quality" are ca } 65 \% \text { cheaper which represents figures between EUR } \\
\text { 20, ooo for the average lot. } \\
\text { Method: Hedonic pricing. }\end{array}$ \\
\hline $\begin{array}{l}\text { Tyrväinen et al. } 2014 \text {. } \\
\text { Ruka-Kuusamo area, northeastern } \\
\text { Finland. }\end{array}$ & $\begin{array}{l}\text { Domestic and foreign tourists' demand for and } \\
\text { willingness to pay for enhanced forest amenities, in } \\
\text { particular landscape values and biodiversity, in } \\
\text { private forests. Captures use value, option value. }\end{array}$ & $\begin{array}{l}\text { Both foreign and domestic tourists were willing to pay for improvements in forest landscape, in terms } \\
\text { of less frequent clear-cutting and site preparation areas along the routes, as well as for increased } \\
\text { biodiversity. Landscape quality: less traces of intensive forestry operation: EUR 11-12/visitor/week, } \\
\text { decrease of outdoor routes in private forests: EUR 10/visitor/week (compensation demand). } \\
\text { Method: choice experiment. }\end{array}$ \\
\hline
\end{tabular}


Juutinen et al. 2014

Finland, sampling regions Lapland

(Northern Finland), Kainuu (Eastern lakes and rivers, habitats for game birds, quality of

Finland), Tavastia Proper (Southern scenery). The study estimates whether the

Finland).

Huhtala \& Lankia 2012

Finland.

Grammatikopoulou et al. 2012.

Finland.

Arcadis et al., 2011.

demonstrating economic benefits of conservation

measures. Increase in utility of recreational visits

extent LWF Gesse) after the introduction of

conservation measures for Arctic fox and

reintroduction of Lesser-fronted Goose. Captures use value.

Fredman \& Emmelin, 2001.

Mountain region Femundsmarka

National Park (Norway), and the

Nature Reserves Rogen (Sweden)

and Långfjället (Sweden).

Willingness to pay for an outdoor recreation trip to the mountain region. Captures use values. from chances to see Arctic fox (and to a lesse

Despite regional differences in preferences, people in all parts of Finland valued the recreationoriented management considerably. Nationwide, the aggregate benefits clearly exceeded the estimated opportunity cost. Aggregate welfare effects of EUR 149 million/year, opportunity costs EUR 13 million/year.

Method: Choice Experiment.

Recreation value is estimated to be about EUR 170-205 per trip. The presence of algae that prevent aquatic recreation decreases the value per trip by $40 \%$, and the lack of a beach reduces it by $45 \%$. The aggregate non-market benefits of the use of the current summer home stock are considerableapproximately EUR 500 million per annum. Impacts should be balanced against the social costs of second homes when designing environmental policies on leisure-time housing. Method: travel cost method.

The most valued attributes (MWTP) were the renovation of production buildings and the presence of grazing animals. The benefit-cost ratio of landscape management measures could be improved by producing simple positive focal points such as presence of animals as a landscape attraction and the avoidance of landscape damage due to ramshackle production buildings. Method: Choice Experiment.

Present Value of EUR $15.28 \mathrm{~m}$ (2010) for the period 2011-2030. Insecurities because of value transfer. Value from arctic fox probably an underestimation.

Method: Value Transfer.

Max WTP of SEK 4,058/person/ trip (1998) (average trip =seven days). WTP differed between visitor groups as they expressed different preferences regarding wilderness management, restrictions, human impact and other users.

Method: CVM. 
Nikodinoska, Paletto, Franzese and Tourists where asked about there WTP for Jonasson 2015.

Sweden, Abisko National Park.

Schägner et al., 2016. All National Parks in Denmark, Sweden and Norway.

Bue Bjørner \& Termansen, 2014 Denmark.

Saelen and Ericson, 2013 Norway, Oslo.

Olaussen and Liu, 2011.

Norway, Norwegian rivers.

Bostedt \& Lundgren 2010.

Sweden, Sami regions. Valuation of Ecosystem Services in protected areas. Activities to adopt to climate change with the aim to preserve ecosystem services.

Provisioning services included wood, berries and mushroom, water provision and reindeer pasture, while cultural services included tourism and

aesthetic values. Captures non-use and use values.

One time lump sum per person of EUR 6.20 (2015) for provisioning services and EUR 4.09 (2015) for cultural services. Cultural services where valued lower than supporting, provisioning and regulating services. This was probably due to a potential trade of between cultural services and conservation activities.

Method: CVM

Mapping recreational visits of European National Parks by combining statistical modeling and unit value transfer. Total recreational values in all nationa parks in the three countries. Captures use values.

Annual recreational value of EUR 556,236,000 for Denmark; EUR 55,700,000 for Sweden and EUR 15,404,000 for Norway. Total visits Denmark: 77,326,000; Sweden: 7,773,000; Norway: 2,150,000. Method: Value Transfer.

The recreational value of 2,475 major recreationa sites including forests, open areas, beaches and parks in Denmark. Estimation of recreationa

Average annual value of DKK 8,000/ha, but value ranges from DKK 240-700,000/ha. The main drive for value is proximity to densely populated areas, as well as available substitute sited. The value is higher if it is part of Natura 2000.

values from the different sites. Captures use value. Method: Travel cost.

Recreational value of different winter conditions in Oslo forests. Captures use value.

Climate change leads to reduced snow. The study estimates forest users' willingness to pay for trips to forest under different conditions (skiing conditions, bare ground, wet snow). Snow conditions correlate with the highest WTP per trip. WTP for bare conditions and wet snow is $40 \%$ and $77 \%$ less. Study concludes that climate change may reduce the recreational value for forest users considerably. Method: Choice experiment.

The article explores to what extent escaped farmed According to the study, the presence of escaped farmed salmon may reduce WTP for recreational salmon from fish farms affect WTP for recreational fishing up to $85 \%$ compared to a situation with a 'pure' wild salmon stock.

fishing of Atlantic salmon.

Method: Contingent valuation

The study estimates the cultural heritage value connected to the Swedish Sami and reindeer

herding culture.
The study shows that the WTP for sustaining the cultural heritage of the Sami reindeer industry was SEK 240 /household /year. Aggregation of the total cultural benefits to the entire Swedish

population was estimated to SEK 500-900 million.

Method: Contingent Valuation Method. 


\section{Appendix 2: Studies that illustrate the economic values associated with biodiversity}

Table 2: Studies that illustrate the economic values associated with biodiversity

Author, year and country Description $\quad$ Valuation result

Kniivilä et al. 2002, Kniivilä 2004

Finland, llomantsi and Northern

Karelia.

Haltia, 2015

Finland.

\section{Economic value of nature conservation in}

llomantsi municipality, cost-benefit analyses

local and regional levels. Captures use and non-

use values for local residents.

Increased forest conservation in Southern

Finland. Captures non-use values, use values.

Juutinen et al. 2011

Oulanka National Park

Northeastern Finland.

\section{Tyrväinen et al. 2014.}

Ruka-Kuusamo area, northeastern

Finland.

Hougner, Colding and Söderqvist

2005.

Sweden,

Park.

Nikodinoska, Paletto, Franzese and Jonasson 2015.

Sweden, Abisko National Park.

Different tradeoffs that evolved in park development scenarios were valued. Specifically, focus is on biodiversity and recreational services. Use and non-use values of park visitors.

Domestic and foreign tourists' demand for and willingness to pay for enhanced forest amenities, in particular landscape values and biodiversity, in private forests. Captures especially use value, option value.

Seed dispersal services performed by the Eurasian Jay that supports seed-dispersed a

\section{Valuation result}

Aggregate conservation benefits exceed opportunity costs at regional level, but not at local level.

Study relied on CV to apply a cost-benefit analysis.

The results show that Finnish citizens support increased forest conservation. The median WTP in the contingent valuation was EUR 72 , i.e. $50 \%$ of respondents supported increased conservation if the costs per household did not exceed EUR 72. The mean WTP estimates were sensitive to modelling assumptions and assumptions concerning the nonrespondent preferences. Uses Contingent valuation and Choice experiment.

The increase of biodiversity was the most highly valued feature by the national park visitors. The protection of biodiversity and recreational and tourism use of national parks can cause conflicting welfare effects if managed in inappropriate ways. Increasing the number of visitors, expanding present

if combined with shrinking biodiversity, are welfare reducing managerial actions in national parks. Method: Choice experiment. willing to pay for improvements in fores of less frequent clear-cutting and site preparation areas along the routes, as well as for increased biodiversity. Positive change in biodiversity (endangered species populations increase by $10 \%$ ): willingness to pay EUR 10/visitor/week; decrease (10\% of species extinct): compensation demand EUR 37/visitor/week. Method: Choice Experiment.

The services performed by Eurasian Jays were estimated to SEK 35,000-160,000 (2005) depending on seeding or planting technique to replace the services. Method: Replacement cost. 
Broberg 2007, Sweden, submountainous area (north west).

\section{Arcadis et al., 2011.}

Sweden, Vindelfjällen Natura 2000 introducing conservation measures, such a

Bredahl Jacobsen et al., 2011. Denmark, three different habitats - populations above survival. It estiamtes WTP forests, open fields, along lakes and $f$ streams.

Busse Nielsen et al.,2007. Denmark.

Lienhoop \& MacMillan, 2007. Iceland.

Broberg \& Brännlund, 2008. Sweden. protection program for Arctic fox and reintroduction of Lesser-fronted Goose in Vindelfjällen Natura 2000.

Captures use and non-use values. The study focuses on valuation of wildlife

Assesses the non-timber value of old-growth forests in Sweden. Respondent were asked about their WTP for preservation of old grow forests. Captures use and non-use values. wildlife".

Captures both use and none-use values, and focus particularly on existence value.

The study estimates Danish public preference for variations in important forest characteristics such as tree species composition, the presence of dead trees left for natural decay and tree hight structure.

ates the costs (in terms of lost welfare) from loss of wilderness (split into flora, fauna, geological features and cultural heritage) from the development of three hydro power

plants in a wilderness area.

Capture use and non-use values.

The study estimated Swedish citizens WTP for policy package aimed at preserving the four large predators in the Swedish fauna (wolf, wolverine, bear and lynx).

Estimates predominately non-use values.
The study showed a WTP of SEK 290 (2007) per person divided on five years for implementation of the preservation program. Aggregate benefits of SEK $g$ billion (2007). Method: CVM.

The conservation measures generate values of EUR 13.74-16.66 million for genetics/ species diversity from arctic fox and LWF Geese for the time period 2011-2030. Method: Value transfer

Danish citizens had a WTP for endangered species of DKK 40-1300/household/year for achieving "rare but not endangered"; DKK 30-1400/household/year for achieving the status "common";

Estimations of WTP for "general wildlife" with and increase of 25\% was DKK 270-1,300 /household/year and an increase by $50 \%$ DKK of $200-570 /$ household/year. Method: Choice Experiment.

A scenario were the baseline (even-aged confiers with no dead trees left for decay) with a mixture of conifers and broadleaves, and leaving dead trees for decay hade the highest WTP of DKK 1939 (per person and year).

Method: Choice Experiment.

The study found a WTA, i.e. what the respondents required in compensation to accept the development, of ISK 780,104 (2007, $\rightarrow$ approx. EUR 6,500) per household and year. Method: CVM

The results show a mean WTP of SEK 300 (2008) for implementation of the preservation program. The mean WTP differ between different areas in Sweden. For example, the mean WTP for people living in Stockholm was SEK 379, while it was SEK 130 for people in non-rural wolf territories. Method: CVM. 
Author, year and country

Hasund et al., 2011.

Sweden.

Lindhjem et al., 2015.

Norway.

Lindhjem \& Mitani, 2012.

Norway.

Aanesen et al., 2015

Norway
The study focuses on different elements and environmental qualities such as different levels of biodiversity in agricultural landscapes.

Captures use and non-use values.

The study estimates benefits and costs of increased forest conservation in Norway. Captures non-use values and use values.

The study estimates Non-industrial private forest owners' preferences and willingness to accept compensation (WTA) to participate in voluntary forest conservation.
Elements such as stone walls, ditches and headlands with more biodiversity are worth SEK 390/y more than elements with little biodiversity. Grasslands with three red-listed species is valued to SEK 179/y more than grassland without red-listed species and to SEK 194/y more if there are six red-listed species.

The value of cultural heritage and recreational areas with "large grassland objects surrounded by other similar grounds" is SEK 103/y higher than "small and isolated grassland objects".

WTP for Grasslands that the respondents often visit or see is valued SEK 235/y higher than grasslands that they will probably never see.

Method: Choice Experiment.

The results show a mean willingness to pay for increased conservation of NOK 1,039 to 1,300 per year /household (2007) depending on the scope of the conservation plan. Social benefits outweigh costs of conservation by a large margin.

Methods: Contingent valuation and cost-benefit analysis.

The study shows that the willingness to accept compensation is negatively related to the size of the forest holding and absentee ownership, and positively related to the share of the forest classified as productive. The overall mean WTA per year per hectare is estimated at NOK 1,800 . Costs of reaching the conservation goals can be saved by targeting small and relatively less productive forests and absentee owners first, before considering increasingly expensive forest areas. Method: Contingent valuation.

The study estimates the willingness to pay for The study shows that the WTP for further protection of CWC was not affected by the fact that marine preserving cold-water coral in Norway (example industries could be adversely affected by CWC protection. The possibility that CWCs play an of an unfamiliar public good). Captures use and non-use values. important role as habitat for fish was the single most important variable to explain respondents' WTP. Average WTP for CWC protection was EUR 274-287. The survey revealed a high degree of preference heterogeneity.

Method: Discrete choice experiment implemented in a valuation workshop setting. 


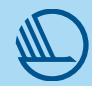

Nordic Council of Ministers

Ved Stranden 18

DK-1061 Copenhagen $\mathrm{K}$

www.norden.org

\section{Economic values from the natural and cultural heritage in the Nordic countries}

Natural and cultural heritage represent key assets that deliver different kind of benefits to citizens in the Nordic countries. This report illustrates the economic values at stake and discusses the important and inevitable key trade-offs facing decision-makers charged with managing these assests. The report has three goals: to briefly describe existing conservation measures in the Nordic countries, to illustrate the type and magnitude of economic values generated by these measures, and to discuss key trade-offs and policy implications arising from the selection of measures, which lead to welfare impacts depending on the level of human use.

The valuation studies reviewed in the report demonstrate real economic values associated with the experiences that natural and cultural heritage provides both in terms of increased welfare and regional economic impacts. 